\title{
DROUGHT-INDUCED VEGETATION SHIFTS IN TERRESTRIAL ECOSYSTEMS: THE KEY ROLE OF
}

\section{REGENERATION DYNAMICS}

Jordi Martínez-Vilalta ${ }^{1,2,3}$ \& Francisco Lloret ${ }^{1,2}$

${ }^{1}$ CREAF, Cerdanyola del Vallès E-08193 (Barcelona), Spain

2 Univ. Autònoma Barcelona, Cerdanyola del Vallès E-08193 (Barcelona), Spain

${ }^{3}$ corresponding author

Name and complete mailing address of the author for correspondence:

8 Jordi Martínez Vilalta

9 CREAF, Campus UAB, Edifici C,

Bellaterra 08193 (Barcelona), SPAIN

1 Tel.: + 34935813811 ;

Fax: + 34935814151 ;

e-mail: Jordi.Martinez.Vilalta@uab.es

This is the author's version of a work that was accepted for publication in Global and planetary change (Ed. Elsevier). Changes resulting from the publishing process, such as peer review, editing, corrections, structural formatting, and other quality control mechanisms may not be reflected in this document. Changes may have been made to this work since it was submitted for publication. A definitive version was subsequently published in Martínez-Vilalta, J. and Lloret, F. "Drought-induced vegetation shifts in terrestrial ecosystems: the key role of regeneration dynamics" in Global and planetary change, vol. 144 (Sep. 2016), p. 94-108. 


\section{Abstract}

Ongoing climate change is modifying climatic conditions worldwide, with a trend towards drier conditions in most regions. Vegetation will respond to these changes, eventually adjusting to the new climate. It is unclear, however, how close different ecosystems are to climate-related tipping points and, thus, how dramatic these vegetation changes will be in the short- to midterm, given the existence of strong stabilizing processes. Here, we review the published evidence for recent drought-induced vegetation shifts worldwide, addressing the following questions: (i) what are the necessary conditions for vegetation shifts to occur? (ii) How much evidence of drought-induced vegetation shifts do we have at present and where are they occurring? (iii) What are the main processes that favor / oppose the occurrence of shifts at different ecological scales? (iv) What are the complications in detecting and attributing drought-induced vegetation shifts? $(v)$ What ecological factors can interact with drought to promote shifts or stability? We propose a demographic framework to classify the likely outcome of instances of drought-induced mortality, based upon the survival of adults of potential replacement species and the regeneration of both formerly dominant affected species and potential replacement species. Out of 35 selected case studies only eight were clearly consistent with the occurrence of a vegetation shift (species or biome shift), whereas three corresponded to self-replacements in which the affected, formerly dominant species was able to regenerate after suffering drought-induced mortality. The other 24 cases were classified as uncertain, either due to lack of information or, more commonly, because the initially affected and potential replacement species all showed similar levels of regeneration after the mortality event. Overall, potential vegetation transitions were consistent with more drought-resistant species replacing less resistant ones. However, almost half (44\%) of the vegetation trajectories associated to the 35 case studies implied no change in the functional type of vegetation. Of those cases implying a functional type change, the most common one was a transition from tree- to shrub-dominated communities. Overall, evidence for droughtinduced vegetation shifts is still limited. In this context, we stress the need for improved, longterm monitoring programs with sufficient temporal resolution. We also highlight the critical importance of regeneration in determining the outcome of drought-induced mortality events, and the crucial role of co-drivers, particularly management. Finally, we illustrate how placing vegetation shifts in a biogeographical and successional context may support progress in our understanding of the underlying processes and the ecosystem-level implications.

Keywords: Drought; Management; Mortality; Regeneration; Succession; Vegetation shifts 


\section{Introduction}

The distribution of vegetation is largely determined by climate and, in particular, by temperature and water availability (Woodward, 1987). Ongoing climate change is modifying climatic conditions worldwide, with a general trend towards warmer temperatures globally and lower water availability in many regions of the Earth (IPCC 2014). Increased frequency of intense and hotter droughts have already been associated with widespread episodes of vegetation die-off (Allen et al., 2010, 2015) and with increases in background (noncatastrophic) forest mortality rates in some areas (Mantgem et al., 2009; Peng et al., 2011). There is no doubt that widespread plant mortality could result in dramatic modifications in forests and other vegetation types, impacting the ecosystem services they provide to society (Anderegg et al., 2012). It is also clear that ecosystems will eventually adapt to the new climatic conditions. What is less clear, however, is how dramatic these changes will be, given the existence of strong stabilizing processes and the relatively high capacity of vegetation to absorb disturbances avoiding major changes in structure, composition and function (Connell and Ghedini, 2015; Lloret et al., 2012; Reyer et al., 2015). In particular, it remains to be established how close different ecosystem types are to climate-related tipping points and how likely it is that they suffer catastrophic regime shifts (Scheffer et al., 2001) under current and future climate conditions.

Here, we review the published evidence for recent drought-induced vegetation shifts worldwide, at any spatial scale ranging from local to continental. We first provide some background on the relationship between climate and vegetation distribution from a biogeographical perspective, focusing on drought. We then outline the state of the art in drought-induced mortality research and finally move to the core of the article in which we address the following questions: (i) what are the necessary conditions for vegetation shifts to occur? (ii) How much evidence of drought-induced vegetation shifts do we have at present and where are they occurring? (iii) What are the main processes that favor, and oppose, the occurrence of shifts at different ecological scales? (iv) What are the complications in detecting and attributing drought-induced vegetation shifts? (v) What ecological factors can interact with drought to promote shifts or stability?

\section{Climate and the distribution of vegetation}


The influence of climate on vegetation distribution is one of the best-established paradigms in ecology, at least at regional and continental scales (Woodward, 1987). Low temperatures and freezing limit hydraulic conductance and tissue integrity and low water availability reduces water transport capacity and carbon assimilation, potentially leading to hydraulic failure or carbon starvation (McDowell et al., 2011). The combination of high temperature and low rainfall results in a strong conflict between high atmospheric water demands and temperature regulation, on one side, and the need to reduce water use to accommodate low water availability on the other side. Accordingly, models considering the balance between water availability and demand are able to explain vegetation distribution to an important extent (Neilson 1995), illustrating the importance of drought conditions on determining vegetation composition, structure and functioning (Vicente-Serrano et al., 2013; Williams et al., 2013).

Changes in climate at the global scale are expected to affect general patterns of vegetation. Great effort has been devoted in recent decades to elucidate these modifications by using dynamic global vegetation models. These models are mainly based on the functional response of vegetation types to climate variables (Sitch et al., 2003). This mechanistic approach, together with the need to up-scale from local to continental scales has led to the use of plant functional types, which in fact often correspond to biome types, merging species with similar performance and habitat requirements and moving the modeling focus towards vegetation functional traits. Importantly, plant functional types are also designed to generally describe and quantify vegetation contributions to ecosystem properties and services (Bonan et al., 2002; Quétier et al., 2007). Thus, the distinction between the taxonomic, species-based conception of vegetation and the functional, traits-based one is important when considering vegetation shifts. Overall, these models point to important latitudinal movements of biome ecotones in the near future (Tang and Beckage, 2010). However, a key unresolved issue is the temporal dynamics of the transitions (i.e., gradual versus abrupt changes), which in turn result from the interaction of climate with other drivers, such as land use transformations, biota migrations and changes in fire regimes (Higgins and Scheiter, 2012; Reyer et al., 2015).

There are also a number of reasons why the accuracy of the predictions derived from vegetation models has been questioned, including methodological shortcomings related with data sources and modeling procedures (e.g., Moorcroft et al., 2001; Thuiller et al., 2008). In addition, difficulties in obtaining reliable predictions at local and landscape scales may be explained by species autoecology (genetic, ecophysiological and population responses to 
environmental variability), biotic interactions (considering the network of facilitative and antagonist relations between plants) and historical background (including biogeographical legacy, disturbance regime, and changes in forest management and land use). All of these factors are relevant to interpretation of climate-induced vegetation shifts at landscape and stand levels by reinforcing or counterbalancing the theoretical equilibrium between climate and plants (García-Valdés et al., 2015).

The existence and characteristics of vegetation shifts can be studied from paleohistorical records. There is abundant literature reporting a correspondence between vegetation change and climate, particularly drought, across a variety of biomes (Calò et al., 2013; Clifford and Booth, 2015; Schmieder et al., 2013; Shuman et al., 2009). There are, however, important limitations associated with this type of paleo-studies (cf. Swetnam et al., 1999). First, paleorecords commonly have coarse temporal resolutions from an ecological perspective, as abrupt transitions of woody vegetation may occur at decadal scales. Advances in dating resolution are providing support for the existence of vegetation shifts at centennial scales (Williams et al., 2002), and we expect finer resolution to be available in the future (i.e., Calò et al., 2013). Second, the attribution of vegetation changes to the climate's influence is not always unequivocal because climate changes are inferred from indirect sources, typically sedimentary measures and biological indicators like pollen (i.e., Calò et al., 2013; Schmieder et al., 2013) that should be complemented by other climate proxies, such as stable isotopes (Shuman et al., 2009). Studies in temperate forests in NE North America provide an example of the correspondence between abrupt climatic events involving drought - estimated from hydrogen stable isotopes - and rapid vegetation changes at temporal scales that are reasonably close to ecological processes (500 years) (Shuman et al., 2009). The relationship between climate and vegetation shifts, however, is often complex due to the interaction with other drivers, particularly disturbance regimes, involving insect outbreaks, wildfires and human activity (Calò et al., 2013; Clifford and Booth, 2015; Foster et al., 2006). In short, at relatively long temporal and broad spatial scales the strong overall relationship between climate and vegetation changes is firmly sustained, but higher resolution information that could elucidate the nature and velocity of such relationships at finer scales merits further research.

\section{Overview of recent drought-induced vegetation die-off}

Drought-induced vegetation mortality has been reported in many areas worldwide, frequently associated with high temperatures, and the number of reported mortality episodes has 
increased dramatically over the last years (Allen et al., 2010; Williams et al., 2013). There is some concern, however, regarding the extent to which this trend reflects a global increase in vegetation mortality or the recent increase in detection effort (Martínez-Vilalta et al., 2011; Steinkamp and Hickler, 2015). In addition, the multiplicity of disturbances affecting forests and the diversity of factors that may contribute to observed mortality patterns makes the attribution of causes difficult (cf. Allen et al., 2015; McDowell el al., 2015). In many cases, for instance, the effects of drought interact with those of rapid successional dynamics associated to changes in forest management (e.g., Vilà-Cabrera et al., 2010), and disentangling these two effects remains challenging.

Despite much research effort, the mechanisms underlying drought-induced plant mortality remain insufficiently understood (McDowell et al., 2008, 2011; Sala et al., 2010), and a definitive classification of plant physiological strategies to face drought is still lacking (Klein, 2014; Martínez-Vilalta et al., 2014). An important outcome of recent studies on the mechanism of drought-induced mortality is the realization that water and carbon economy of plants are tightly linked during extreme drought, so that failures in the water and carbohydrate transport systems (hydraulic and phloem failure, respectively) and extreme carbohydrate depletion (carbon starvation) are likely to co-occur (Mencuccini et al., 2015; Parolari et al., 2014; Sevanto et al., 2014). The contribution of biotic factors and their interactions with the physiological mechanisms of mortality (Gaylord et al., 2013; Oliva et al., 2014) further complicates attribution (Anderegg et al., 2015b). The complexity of mortality mechanisms is problematic because it limits our capacity to assess the causes of a given mortality event, as well as our capacity to predict when and where these events are likely to occur in the future (McDowell et al., 2013). In that regard, comparative physiological studies of drought responses of coexisting species, either in the field or under controlled experimental conditions (e.g., Garcia-Forner et al., 2015; Nardini et al., 2015), are likely to be particularly useful.

Many studies have found an association between climate anomalies and drought-induced mortality at different spatial and temporal scales (e.g., Fensham et al., 2009; Suarez and Kitzberger, 2010; Mitchell et al., 2014). Spatiotemporal patterns of drought-induced vegetation mortality, however, tend to be complex. At relatively small spatial scales (stand to catchment), high mortality rates often are associated with shallow soils (Gitlin et al., 2006; Vilà-Cabrera et al., 2013), higher exposure to radiation (Gitlin et al., 2006), low topographic soil moisture (Galiano et al., 2010), dense stands (i.e., higher competition) (Guarín and Taylor, 2005; Vilà- 
Cabrera et al., 2013), and biotic agents (Gaylord et al., 2013). However, exceptions are common, and even within a particularly well-documented system such as the piñon-juniper woodlands in SW USA the degree of discrepancy between studies can be remarkable (Meddens et al., 2015), likely reflecting high spatial variability in climate, soils, topography and disturbance history (Romme et al., 2009; Swetnam and Betancourt, 1998). In general, complex interactions between factors leading to mortality are not always easy to capture in statistical models based on 'opportunistic' field observations.

At broad spatial scales, additional processes need to be considered. For instance, changes in species dominance along aridity gradients imply that drought resistant species (in absolute terms) tend to occupy drier habitats and may not be necessarily closer to their physiological limits (relative to the local conditions where they live). As a result, predicting what species and populations are more vulnerable to a given precipitation anomaly is not straightforward. This is consistent with observations of drought-induced mortality in wet environments (e.g., tropical rainforests (Phillips et al., 2009)) and with the fact that hydraulic safety margins have been reported to be similar across biomes at the global scale (Choat et al., 2012). Within species, functional and morphological traits vary widely along environmental gradients (e.g., Siefert et al., 2015; Vilà-Cabrera et al., 2015), and the balance between plasticity and local adaptation processes becomes critical (Valladares et al., 2014). Despite all these complications, recent studies show promising avenues. For instance, populations occupying more marginal locations within the species' bioclimatic niche are more affected by drought-induced die-off in Mediterranean woody communities (Sapés, 2013). In another recent report, climatic water deficit simulated from a hydrologic model was able to predict regional patterns of Populus tremuloides mortality with 75\% accuracy (Anderegg et al., 2015a). Similarly, a logistic regression using species identity, mean climate and climate anomalies for a given year provided a reasonably good fit to regional patterns of forest decline in NE Spain (Chaparro, 2013).

\section{On the necessary conditions for vegetation shifts to occur}

Vegetation shifts are a particular case of ecosystem regime shifts, which can be defined as large, relatively rapid and persistent reorganizations of the state of ecosystems (Brook et al., 2013). Regime shifts may result from a large permanent change in environmental conditions, but may also result from relatively small or transient changes in environmental drivers (Scheffer et al., 2001; 2012). This second type of regime shifts implies the presence of tipping 
points, and is frequently (but not always) associated with the existence of multiple 'stable' states (Petraitis, 2013). Tipping points are associated with positive feedbacks that, once a critical threshold is passed, propel change toward an alternative state (Scheffer et al., 2012). The kind of vegetation shifts we are concerned with here occur when a pulse-type disturbance (i.e., a drought) triggers a reorganization of the ecosystem that is maintained after environmental conditions return to pre-disturbance levels. This definition of drought-induced vegetation shifts is an example of catastrophic regime shift and involves multiple 'stable' states and hysteresis (the return path to the original state differs from the original trajectory that led to the current state, making the change difficult to reverse) (Scheffer et al., 2001).

Several studies have documented evidences of catastrophic regime shifts in ecosystems (Folke et al., 2004; Scheffer et al., 2001). Although most of them come from aquatic environments (particularly lakes and marine systems), there are also examples from terrestrial ecosystems. Among those, some of the best characterized cases include desertification in the Sahara region (Foley et al., 2003; Janssen et al., 2008), forest-woodland ecotones (Allen \& Breshears, 1998), transitions between forest, savanna and treeless states in tropical systems (Hirota et al., 2011; van Nes et al., 2014), and peatland dynamics (Hilbert et al., 2000) or transitions between forests, treeless tundra and steppe in the boreal biome (Juday et al., 2015; Scheffer et al., 2012). However, detecting multiple 'stable' states and catastrophic shifts from temporal and spatial patterns is difficult, mainly due to the difficulty of having proper controls and longenough time series (Petraitis, 2013; see also Andersen et al., 2009; Scheffer and Carpenter, 2003). The use of spatial patterns is particularly problematic, as shown, for instance, by the controversy around the use of spatial vegetation patterns (in particular, their patch size distribution) as a suitable indicator of catastrophic vegetation shifts in drylands (Kéfi et al., 2007; Maestre and Escudero, 2009; Rietkerk et al., 2004).

We argue here that a demographic approach provides a useful framework for detecting and assessing potential vegetation shifts. From a demographic perspective, a vegetation shift implies an abrupt change in the relative abundances of dominant species in a community (composition), and should be reflected in the demographic rates of the species involved (Lloret et al., 2012). In particular, such a change requires that the formerly dominant species are replaced by other potentially dominant ones, which would normally be present in the community before the drought but may also colonize after it. The typical process leading to a drought-induced vegetation shift can be conceptualized in four steps: (i) a drought event 
causes high adult mortality rates in (at least) one dominant species; (ii) these adult mortality rates are higher than those experienced by one or more potential replacement species; (iii) these potential replacement species show substantial regeneration; and (iv) regeneration of the initially dominant species is very low or absent. However, other combinations may also lead to a vegetation shift (see Figure 1 for a complete classification).

More generally, and based on the criteria presented in the previous paragraph, we can distinguish several situations (Figure 1):

Vegetation shift. Arguably, the most important condition for a vegetation shift to occur is that regeneration of a potential replacement species is successful during a relevant time period after the mortality event. If, in addition to that, there is no regeneration of the formerly dominant species, the evidence for a shift is clear. In principle, the shift will be faster if adults of the potential replacement species have survived (SSf in Figure 1) than if not (SSs). No shift. Vegetation composition will remain unchanged in the mid-term if the formerly dominant species regenerates while the potential replacement species does not. In these cases, we may refer to reversal (RV), when adults of the potential replacement species survive achieving transitory dominance, or to self-replacement (SR), when such survival is not observed. Uncertain outcome. If regeneration of both the formerly dominant and the potential replacement species is observed, the final outcome is uncertain. Obviously, the likelihood of a shift is higher if there is adult survival of the potential replacement species (UNa) than if not (UNc). In addition, if there is no regeneration of the dominant or potential replacement species, but there is survival of adults of this latter species, the outcome is also uncertain (UNb), although a species shift may still take place in the long-term.

Biome shift. When there is neither regeneration nor survival of adults of the dominant or potential replacement species, the most likely outcome is colonization by a new species not represented in the original community or, in extreme cases, complete loss of vegetation (i.e., transition to bare soil). We refer to such changes as biome shifts (BS).

Temporal considerations are critical in any framework aiming at classifying potential vegetation shifts. In our case (Figure 1), the reference time frame is the typical generation time of the dominant species in the community (i.e., a shift will occur if the identity of the dominant species changes after one generation). We assume that observations on mortality and regeneration are taken shortly (up to a few years) after the mortality event, as is usually the case, and are used to assess subsequent community dynamics. In order for vegetation shifts to 
301

302

303

304

305

306

307

308

309

310

311

312

313

314

315

316

317

318

319

320

321

322

323

324

325

326

327

328

329

330

331

332

333

334

be realized, measured demographic rates should be good estimates of per-capita rates of population growth, and should continue at similar rates for long enough to drive the system into a new state (cf. Petraitis, 2013). For instance, enough time without other major disturbances is required for the new community to develop. The opposite case should also be considered, as repeated droughts may lead to disproportionate effects relative to the impact of a single drought of the same intensity, due to legacy effects (Anderegg et al., 2015c). In addition, many vegetation types (particularly forests) are inertial systems where adults can live for hundreds of years and mortality and recruitment may depend on different environmental drivers and be highly decoupled in time (Shugart and Urban, 1989). Under directional climate change, a shift in such systems may occur simply because the original ecosystem cannot develop under the new conditions, even if it could have been maintained in the absence of the disturbance triggering the shift (Dobrowski et al., 2015; Smith et al., 2009).

\section{Characterization of recent drought-induced vegetation shifts}

We conducted a literature review of papers reporting drought-induced vegetation shifts. We started by searching the Web of Science (accessed 15/05/2015) with the following keywords (topic search): (vegetation OR forest OR woodland OR shrubland OR biome) AND (shift\$ OR change\$ OR transition\$ OR replacement\$ OR substitution\$ OR succession) AND drought\$ AND (mortality OR die-off OR dieoff OR decline OR die-back OR dieback) AND (regeneration OR recruitment). This search resulted in a list of 319 papers. The abstracts of all these papers were checked to select papers fulfilling the following criteria: (i) they were field-based, original research papers (i.e., reviews, studies under experimentally controlled conditions and purely modelling papers were excluded); (ii) they studied 'natural' vegetation (e.g., forest plantations were excluded), (iii) they studied the effects of a drought event that occurred at a well-defined point in time (i.e., a pulse event) after 1950; (iv) they measured or made some inference on the vegetation dynamics after the drought event. The list was completed with a few additional case studies from Allen et al. (2010) or other key references that had not been detected in our initial query. Selected papers were organized by case studies, so that articles studying a similar transition within the same broadly defined region were pooled together to avoid giving extra weight to more intensively studied systems, and each case was classified according to the framework presented in Figure 1 (Table 1).

Our final list included 35 case studies (Table 1 and Figure 2). The majority of them $(N=24)$ were classified as uncertain according to the framework in Figure 1, whereas 7 corresponded 
to species shifts, three to self-replacements and one to a biome shift (Figure 2). Uncertain cases were mostly associated to two different situations. The first was lack of information regarding either mortality of the potential replacement species or regeneration of the affected or replacement species $(N=7)$. Secondly, in 15 instances uncertainty arose from similar levels of regeneration of both the initially affected and the potential replacement species, precluding inferences on the mid-term trajectory of the study system. Finally, in two cases (piñon-juniper woodlands in SW USA and beech in England) uncertainty resulted from inconsistencies in the regeneration patterns (of the affected and potential replacement species, respectively) reported in different studies carried out in the same systems. We note, however, that the piñon-juniper vegetation occurs over a wide range of environmental conditions and includes different pine and juniper species (Romme et al., 2009). Therefore, inconsistencies in regeneration patterns across studies likely reflect different trajectories (including SSf, UNa and probably also BS) in different parts of the range of this vegetation type.

The seven cases corresponding to species shifts occurred in temperate, Mediterranean and tropical climates, whereas the recorded biome shift was reported in a dry climate (Table 1 and Figure 2). The low sample size makes it difficult to reach any strong conclusion on the spatial distribution of these shifts, but they seem to be widely distributed across biomes and climate types. Regarding the spatial scope, reported vegetation shifts went all the way from local to subcontinental scales. In five cases other drivers besides drought were mentioned in the corresponding papers, including biotic agents and land management (e.g., grazing, fire use).

To explore the functional implications of the potential vegetation shifts described in the different case studies we classified them depending on the functional type of the affected dominant species and the potential replacement one(s) (Table 1). Functional types were defined based on broad plant classification (needleleaf / gymnosperm vs. broadleaf / angiosperm), leaf habit (deciduous vs. evergreen), and growth form (tree, shrub, herb), similarly to Lawrence and Chase (2007). Only six thus defined functional types were represented in our case studies: needleleaf evergreen tree, NET; broadleaf evergreen tree, BET; broadleaf deciduous tree, BDT; broadleaf evergreen shrub, BES; broadleaf deciduous shrub, BDS; and needleleaf evergreen shrub, NES. When there was more than one functional type represented in the affected dominant species or in the potential replacement species within a case study, we considered as many trajectories as combinations of functional types occurred in each case. 
370 When all cases were considered (39 individual trajectories), there were 17 trajectories (44\%) implying no change in functional type even if the vegetation shift was realized (i.e., the affected and potential replacement species belonged to the same functional type) (Figure 3). BET -> BET transitions (a broadleaf evergreen tree being replaced by the same or another species of the same functional type) were the most common situation overall ( $N=11$ trajectories). Directional (i.e., non-circular) trajectories originating from NET and BET were more common than directional trajectories ending in these functional types (10 vs. 4 and 6 vs. 3 for NET and BET, respectively). Overall, there were 10 transitions from trees to shrubs, whereas the opposite change was not observed. Transitions between species with different leaf habit were relatively rare, but were more common from evergreen to deciduous $(N=5$; mostly NET -> BDT) than the opposite $(N=2)$. Only nine trajectories corresponded to species or biome shifts according to our scheme (Figure 1; red arrows in Figure 3). Of these, three corresponded to BET -> BET transitions. Trajectories corresponding to species or biome shifts affected only NET or BET functional types (three in each case).

Finally, the three cases in which self-replacement was observed affected broadleaf evergreen species (two BET, one BES) and occurred in different climatic regions (tropical, temperate and Mediterranean). More generally, a shift seems unlikely, at least in the short term, whenever regeneration of the affected species is observed, even if potential replacement species are also regenerating. If we add the 15 uncertain cases in which there was regeneration of the affected species (UNa, UNc in Figure 1) to the self-replacement cases, we end up with 18 cases (51\% of 35 case studies) in which the weight of the evidence seems to be against the occurrence of a vegetation shift.

393

\section{Drought-induced vegetation shifts in practice: crucial challenges to understanding and} prediction

We only found eight case studies that fulfilled our criteria to be considered drought-induced vegetation shifts (species or biome shifts in Figure 1). And even these cases correspond only to situations in which the available evidence, often representing a short time period, is consistent with the occurrence of a shift; and not necessarily to cases in which these shifts are certain or even likely. We acknowledge that our search criteria were biased towards identifying instances of vegetation change that had been placed in a demographic context (see previous section). Although we accept that this might have resulted in missing some convincing cases of drought- 
403

404

405

406

407

408

409

410

411

412

413

414

415

416

417

418

419

420

421

422

423

424

425

426

427

428

429

430

431

432

433

434

435

436

induced vegetation shifts, we argue that this effect is likely to be minor, as it is difficult to describe and attribute recent (post-1950) vegetation shifts without assessing demographic rates (mortality and regeneration). Considering the low number of drought-induced vegetation shifts we detected, a reasonable first conclusion would be that these shifts are not yet common or detectable. However, this conclusion needs qualification in some respects (see also Hughes et al., 2013). Firstly, vegetation shifts are likely to be inherently rare events, and their detection by standard vegetation monitoring systems, such as national forest inventories, is inefficient. As a result, most reports of vegetation shifts arise from opportunistic studies initiated by scientists as a response to an observed mortality event. While informative, this approach makes it difficult to assess the spatial representativeness of the event and to evaluate the subsequent community dynamics for a sufficiently long period (cf. White and Jentsch (2001) on the importance of the scale of observation). Secondly, and related to the previous point, regeneration is frequently the key ecological process determining long-term community dynamics. However, it rarely has been assessed in studies of drought-induced mortality. Thirdly, recent climatic impacts on vegetation have occurred in the presence of other important drivers, in most cases directly related to human activities (e.g., changes in land-use, grazing practices, forest management, fire use). These three aspects are addressed in the following sub-sections.

\subsection{Need for long term monitoring with sufficient temporal resolution}

Better vegetation monitoring systems are urgently needed if we are to assess how common drought-induced vegetation shifts currently are and make sound projections of how frequent they are going to be in the future (see Allen et al. (2010) and Hartmann et al. (2015) for similar assertions in the context of drought-induced tree mortality). An adequate monitoring system should have, at least, the following characteristics: (i) it should be able to distinguish different vegetation types (i.e., changes in composition), not only changes in canopy structure and physiological state; (ii) it should cover a spatially representative area and have the potential to become global; (iii) it should have sufficient spatial and temporal resolution to detect the processes of interest; and, critically; (iv) it should be long-term. It seems clear that remote sensing holds the greatest promise for such a system, particularly at broad regional or global scales (Hansen et al., 2013; McDowell et al., 2015). However, ground-based inventories also will be essential, as most remote sensing techniques require extensive ground evaluation and frequently lack the desired spatiotemporal resolution (McDowell et al., 2015; Trumbore et al., 2015; although cf. Asner et al., 2016). 
Invited review for Global and Planetary Change

437

438 While standard national forest inventories (NFIs) are well-suited for assessing changes in tree 439 biomass and carbon stocks (e.g., Mohren et al., 2012), they have important limitations for 440 detecting vegetation shifts. Firstly, plot size ( $<1$ ha) and distribution are not designed to 441 capture relatively infrequent events, such as drought-related disturbances. Secondly, the time 442 interval between surveys (frequently $>5$ years) makes it difficult to attribute changes in 443 structure or composition to a specific cause. Thirdly, forest inventories commonly lack 444 accurate information about regeneration, a key process to obtain projections of forest 445 dynamics (see next section). Finally, NFIs do not sample non-forested areas, which seriously 446 limits their capacity to detect changes between forests and other vegetation types. Many of 447 these limitations are shared by forest health monitoring programs, such as the European ICP448 Forests, despite their usefulness for detecting long-term changes in tree condition (e.g., 449 drought-related leaf loss: Carnicer et al., 2013). Standardized, broad scale plot monitoring 450 networks, such as the recently launched CTFS-ForestGEO (Anderson-Teixeira et al., 2014) offer 451 great promise due to their relatively large plot sizes and global coverage, but they still suffer 452 from relatively infrequent surveys ( $\sim 5$ years) and lack of coverage of non-forested areas.

\subsection{It is about regeneration, of course!}

Recent research on drought-induced vegetation change has focused on plant mortality. While this is normal, as mortality is the most conspicuous and immediate effect of an extreme drought, we argue here that this focus should be complemented with a greater emphasis on the demographic responses following the mortality event. Even after devastating adult mortality, a vegetation shift will only occur if the initially affected species is not able to regenerate and become dominant again (Lloret et al., 2012). It is clear from our review that self-replacement or reversal (cf. Figure 1) may be common outcomes of drought-induced mortality events, at least in the short term. This result is not surprising in the context of other disturbances. For instance, self-replacement (cf. direct regeneration) has been long known to be a common response of Mediterranean communities after fire, which originated the term 'autosuccession' (Hanes, 1971; Trabaud and Lepart, 1980). Although we now know that autosuccession does not always occur (Rodrigo et al., 2004), it remains the most common response to wildfire in Mediterranean systems (Pausas et al., 2009) and it has also been reported in many other ecosystem types in response to a variety of disturbances (Johnstone and Chapin, 2006; Zeppenfeld et al., 2015). Of course, the fact that there is regeneration of the affected species soon after a mortality event does not rule out the possibility that a vegetation 
471 shift will occur in the mid-term. This is particularly true in the context of strong directional

472 climate change, as sustained temperature raise and associated drivers (biotic agents, wildfires)

473 may result in future failure of seedling recruitment in areas with good regeneration under

474 current conditions (Allen et al., 2015; Brando et al., 2014; McDowell et al., 2016; Williams et

475 al., 2013).

476

477 In order to understand when and where a species or biome shift is likely to occur, as opposed

478 to self-replacement, we need to place the focus on regeneration dynamics at appropriate

479 temporal scales. The distinction between the 'habitat niche', defined by the requirements of

480 mature plants, and the 'regeneration niche', defined as the requirements for a successful

481 replacement of mature individuals (Grubb, 1977), becomes relevant in that context. Self-

482 replacement will be likely to occur after drought-induced mortality when the regeneration

483 niche of the affected species is at least as wide as its habitat niche, particularly with regards to

484 water availability. It is normally assumed that juveniles of a given species have narrower niches

485 than adults (Jackson et al., 2009), and most studies seem to support this view (e.g., Bell et al.,

486 2014; Dobrowski et al., 2015). In the case of water availability, an important reason for that is

487 that seedlings typically have much shallower root systems than adults (the situation may be

488 different for resprouts; see below), limiting their capacity to access deep water sources (Pratt

489 et al., 2008). However, inherent climatic variability, particularly in water-limited systems, may

490 offer pulses of suitable conditions for regeneration (Swetnam and Betancourt, 1998). The local

491 conditions after mortality events may change substantially relative to pre-disturbance

492 conditions, including likely increases in resource availability per capita (particularly light but

493 also water and nutrients), and reductions in the capacity of the canopy to moderate

494 environmental conditions (temperature, vapor pressure deficit). These changes are likely to

495 interact with each other (von Arx et al., 2013) and, collectively, will determine the likelihood of

496 self-replacement and overall community stability (Frelich and Reich, 1999).

497

498 As in other disturbances, gap size distributions and shade tolerance of the species in the

499 community are likely to play an important role, as well as the fact that tradeoffs between

500 shade and drought resistance are common (Niinemets and Valladares, 2006). Gap sizes opened

501 by drought-induced mortality are likely to be smaller than those characteristic of other

502 disturbances (e.g., fire), and may not be enough to shift the balance in favor of the

503 regeneration of shade-intolerant species. In the case of the relatively shade-intolerant Scots

504 pine in Europe, for instance, adult mortality has been shown to have a negligible or even 
505

506

507

508

509

510

511

512

513

514

515

516

517

518

519

520

521

522

523

524

525

526

527

528

529

530

531

532

533

534

535

536

537

538

negative effect on its regeneration, while favoring the relatively shade-tolerant oaks (Galiano et al., 2013, 2010; Rigling et al., 2013). The fact that shade tolerance of juveniles and adults is correlated across species, albeit with an important scatter (Valladares and Niinemets, 2008), may help predicting community dynamics after disturbance. There is a clear need, however, for further studies assessing seedling performance relative to adults and comparing it among coexisting species under changing environmental conditions.

It is also important to recognize and study the implications of different regeneration strategies. The ability to resprout is a key trait, as it enables the survival of individuals and allows rapid recovery of aboveground biomass after disturbance (Bellingham and Sparrow, 2000; Bond and Midgley, 2001; Clarke et al., 2013). Resprouting is common in many ecosystems (Vesk and Westoby, 2004) and, although it has been studied mostly in the context of vegetation responses to fire, wind throw and clipping, recent papers stress the importance of resprouting in the context of drought stress (Pausas et al., 2015; Zeppel et al., 2014). Drought response strategies frequently co-vary with resprouting ability, which makes it difficult to establish clear associations between this latter trait and vulnerability to drought (Pausas et al., 2015; SauraMas and Lloret, 2010). In general, the fact that resprouters typically recover faster than nonresprouters after disturbance, including drought (Zeppel et al., 2014), implies that reversals and self-replacements (cf. Table 1) may be more common when resprouting species are affected. This situation, however, may only apply to certain drought regimes (Pausas et al., 2015). In particular, the ability of resprouting species to persist is likely to decline as the frequency of extreme droughts increases. This is mostly due to the fact that repeated resprouting requires sufficient time between disturbances for reserves (particularly carbohydrates) to build up again (Canadell and López-Soria, 1998). In addition, some studies have identified physiological differences between resprouting and undisturbed individuals, suggesting that the former are more sensitive to drought (Pausas et al., 2015).

\subsection{Key role of interactions with other drivers}

A necessary condition for the occurrence of a vegetation shift is the differential performance of species in terms of adult survival or the recruitment of new cohorts (Figure 1). In many cases, these differences reflect species-specific tolerances to the conditions generated by standing vegetation or by mortality-induced gaps. There is general consensus on the relevance of multiple factors other than the attributes of the species involved in determining tree death, even in cases where drought is well documented (e.g., Frey et al., 2004; Galiano et al., 2010). It 
539

540

541

542

543

544

545

546

547

548

549

550

551

552

553

554

555

556

557

558

559

560

561

562

563

564

565

566

567

568

569

570

571

572

is more difficult, however, to disentangle the contribution of such factors on species differential responses, particularly because they usually interact to reinforce or stabilize complex feedbacks. These factors typically include pests and pathogens, grazing, pollution, wildfires and microsite conditions, particularly soil characteristics. These co-drivers of vegetation dynamics often operate at fine spatial scales, undermining our capacity to obtain global patterns in the relationship between water availability and tree mortality, except for drier locations (Steinkamp and Hickler, 2015). In our literature compilation, we found that $86 \%$ out of 35 selected case studies recognize the influence of co-drivers. The most common factor was the interaction with biotic agents, which mainly involved pests and pathogens ( $43 \%$ of the cases) and grazing (20\%). Forest management, including logging, was also considered relevant in $23 \%$ of cases; whereas other disturbances, such as wildfires (14\%), seem to play a relevant role only in some regions. The number of studies considering the relevance of non-climatic factors as determinants of recruitment following drought-induced mortality was much lower than those addressing the role of these factors on mortality patterns. In addition, most studies only conducted a general assessment of regeneration without formal test of hypotheses, and particularly the interaction between climatic and non-climatic factors was rarely addressed.

Contributing factors are often a source of uncertainty when assessing vegetation shifts at fine spatial scales given their idiosyncratic variability, but also because we commonly lack information on their historical influence (i.e., land-use, grazing, forest management, disturbance regime). Nevertheless, we can identify different situations according to their potential interaction with drought episodes. First, co-drivers may enhance mortality by establishing synergies with drought conditions. For instance, severe drought induces reserve depletion in trees, increasing their vulnerability to pests and pathogens (Gaylord et al., 2013; Jactel et al., 2011). In turn, these antagonistic attacks could reduce carbon reserves, eventually conducting to a reinforcing feedback between drought and biotic agents (Oliva et al., 2014). The outcome of these interactions may involve time lags, confounding the contribution of different agents and highlighting the importance of considering medium-term tree survival in addition to mortality pulses. For instance, bark beetles may initiate a successful infestation under drought conditions, in some cases eventually reaching a demographic threshold leading to the death of trees that were not severely affected by drought itself (Allen, 2007). Analogously, drought can have strong direct and indirect synergistic effects on wildfires; e.g., fine and coarse fuel loads can temporarily increase and change in structure with droughtinduced tree mortality, which can change the size and severity of fires (along with drought and 
573

574

575

576

577

578

579

580

581

582

583

584

585

586

587

588

589

590

591

592

593

594

595

596

597

598

599

600

601

602

603

604

605

606

land-use), which in turn can jeopardize tree survival and regeneration (Allen, 2007). Ongoing climate changes are projected to foster increased wildfire activity in many ecosystems (IPCC, 2014). In Mediterranean systems, fire risk may rise until fuel loads become too low due to water limitations on vegetation growth, while the new climate conditions become less favorable to post-fire vegetation recovery (Batllori et al., 2013; Loepfe et al., 2014).

Other drivers can contribute to vegetation dynamics without being themselves directly promoted by drought conditions. This is the case of disturbances such as windstorms (Bailo et al., 2004) or pollution (Palik et al., 2011) that further diminish adult survival in addition to drought. Both mortality and post-drought regeneration of Populus tremuloides in N America have been proposed to be impacted by grazing (Worrall et al., 2008), but the contribution of herbivores to the differential performance of dominant and potential replacement species needs further study. Although browsing itself can hardly be linked directly to drought conditions, regeneration control by grazing often occurs in semi-arid ecosystems (Maza-Villalobos et al., 2013; Twidwell et al., 2014). Potentially, other factors may counterbalance drought impacts, increasing resilience (Lloret et al., 2012). Some of these factors can involve biotic interactions, such as facilitation, which in turn can be influenced by climatic conditions, including drought. However, the contribution of positive biotic interactions on post-drought vegetation dynamics has been rarely assessed (Lloret and Granzow-de la Cerda, 2013).

Finally, management constitutes one of the major drivers of vegetation dynamics all over the world and it surely affects the likelihood of drought-induced mortality and subsequent vegetation responses. Management history may increase forest vulnerability to drought through several mechanisms, thus enhancing species shifts. First, management may promote expanding populations to (or beyond) the edge of the species historic distribution, close to its physiological limits of tolerance for both adults and juveniles (e.g., Sánchez-Salguero et al., 2012). Second, increased stand density as a result of past logging (Camarero et al., 2011; Slik, 2004), abandonment (Linares et al., 2010b) or fire exclusion (Breshears et al., 2005; Guarín and Taylor, 2005) may lead to higher competition for water resources. Remaining adult trees and new recruits also may be damaged during wood harvesting (Aynekulu et al., 2011). In addition, regeneration may be depleted due to overgrazing (Linares et al., 2011). At regional scales in arid regions, overexploitation of standing biomass can exacerbate rainfall decline, leading to a positive feedback between bare soil cover and aridity (Gonzalez, 2001). Alternatively, stand density reductions (Grant et al., 2013) or direct promotion of regeneration can boost self- 
607

608

609

610

611

612

613

614

615

616

617

618

619

620

621

622

623

624

625

626

627

628

629

630

631

632

633

634

635

636

637

638

639

640

replacement or vegetation shifts depending on the favoured species. In contrast with drivers that are the result of processes operating at global or regional scales, these more local management actions (grazing control, modification of stand structure, species selection) may be used as tools to delay or modify local trajectories of vegetation dynamics.

\subsection{Functional and biogeographical context}

Altered climatic conditions will eventually lead to changes in vegetation biogeography. Theoretical predictions, niche correlational approaches and process-based models all support future modifications in the distribution of vegetation and biomes (Sitch et al., 2003; Tang and Beckage, 2010). However, in spite of substantial evidence of the occurrence of droughtinduced tree mortality, we are not yet observing widespread vegetation shifts in response to increasing drought conditions. An important necessary condition for these shifts to occur is the existence of a species pool providing potential replacement species. In some reported cases, uncertainty arises because there is no clear replacement tree species (Boehmer et al., 2013; Villalba and Veblen, 1998); in other cases, understory shrubs are the immediate candidates to occupy the gaps opened by tree mortality (Palik et al., 2012, 2011; Saura-Mas et al., 2014; Worrall et al., 2010). In these cases, vegetation responses can often be placed within a successional framework of species replacement following disturbance. The same applies to other studies that point to replacements between coexisting trees with different degree of shade tolerance or successional status in temperate (Galiano et al., 2010; Olano and Palmer, 2003) and tropical forests (Chazdon et al., 2005; Oatham and Ramnarine, 2006). Selfreplacement can also be placed in this successional framework when new cohorts of standing vegetation can tolerate the conditions imposed by drought, as in Mediterranean shrublands (del Cacho and Lloret, 2012; Lloret et al., 2015), or when drought triggers the decay expected to occur in old cohorts (Boehmer et al., 2013). At the other extreme of species pool availability, studies in diverse tropical forests consistently report structural changes leading to shorter species and lower basal area (Zhou et al., 2014, 2013). Although these structural modifications may correlate with compositional changes at the stand level, the existence of directional shifts at the local scale is less clear, given the high spatial turnover of species in these forests (Lingenfelder and Newbery, 2009; Slik 2004; Zhou et al., 2014, 2013) (but see Fauset et al. (2012) for long-term drought). The relevance of the available species pool in determining future vegetation trajectories highlights the vulnerability of many managed, impoverished forests. The enhancement of woody species diversity in forests, particularly if it is based on native species covering a wide range of bioclimatic niches and genetically diverse populations, 
641

642

643

644

645

646

647

648

649

650

651

652

653

654

655

656

657

658

659

660

661

662

663

664

665

666

667

668

669

670

671

672

673

674

constitutes an important management opportunity to improve resilience in forests facing future drier conditions (Jump et al., 2009a; Fauset et al., 2012; Morin et al., 2014; but see Grossiord et al., 2014).

Overall, current evidence does not show generalized shifts in vegetation functional types induced by drought. This is true even where species replacement is likely to occur, supporting the role of species functional redundancy within communities in promoting resilience. This is particularly clear in tropical forests dominated by BET, as stated above (but see Fauset et al. 2012). However, in the instances in which changes in the dominant functional type are predicted, trajectories generally agree with expectations of vegetation responding to drier conditions by favouring species with higher drought resistance. Temperate, relatively moist forests dominated by NET tend to be replaced by BET or BDT species distributed at lower latitudes or altitudes (Bailo et al., 2004; Camarero et al., 2011; Galiano et al., 2010; NavarroCerrillo et al., 2014; Rigling et al., 2013). Analogously, temperate moist forests of Nothofagus dombeyii (BET) tend to be replaced by Austrocedrus chilensis (NET), a species distributed into the drier steppe biome (Suarez and Kitzberger, 2008). The only shift of BDT replacing BET corresponds to drought-deciduous species in the Sahel (Gonzalez, 2001). Finally, there is documentation in several cases of forest change from drought stress towards lower-statured vegetation, dominated by shrubs or smaller trees (Bennet et al., 2015; McDowell and Allen, 2015), while the opposite (transitions to taller vegetation) does not seem to occur.

Vegetation changes can be interpreted by comparing the biogeography of the former dominant and the potential replacement species. Our preliminary results allow formulating the hypothesis that species with affected populations located at the edge of the species' climatic range - thus, close to their physiological limits of drought tolerance - likely would be replaced by species better adapted to water scarcity, and hence distributed over drier environments. This hypothesis is consistent with reported species range shifts along altitudinal gradients, but less evident along latitudinal ones (Jump et al., 2009b). Thus, drought episodes would trigger changes in species distributions particularly at ecotones (Allen and Breshears, 1998). Nevertheless, a proper analysis of the climatic requirements of the species involved and the effect of co-drivers is needed, because populations living at the edge of its climatic distribution may exhibit compensatory demographic mechanisms (Pironon et al., 2015) and may have experienced selective processes enhancing resilience. In spite of the attractiveness of understanding the biogeographical implications of drought-induced vegetation shifts, in 
675

676

677

678

679

680

681

682

683

684

685

686

687

688

689

690

691

692

693

694

695

696

697

698

699

700

701

702

703

704

705

706

most cases our current knowledge does not allow discriminating between alternative processes, preventing us from reaching general conclusions.

\section{Concluding remarks}

Our literature review shows that the available evidence for drought-induced vegetation shifts is still scarce, and suggests that vegetation exhibits a remarkable resilience to extreme drought, both in terms of composition (i.e., self-replacement) and functional properties. Examples of potential vegetation shifts do not seem to be limited to specific climates or vegetation types. In the cases in which the evidence for species replacement is clearer, vegetation transitions seem to favor dominance of species that are: a) more resistant to drought, as inferred by their patterns of distribution or their functional and structural traits; or b) more pioneer in successional status. Given the limited information currently available on drought-induced vegetation shifts from projected changes in climate, specifically including drought conditions, we stress the need for improved, long-term vegetation monitoring programs with sufficient temporal resolution. We also advocate for changes in approaches to the study of drought-induced mortality and its impact on vegetation dynamics. First, we suggest widening the focus to include not only the triggers of vegetation die-off but also the determinants of vegetation responses after mortality, with a particular emphasis on comparative regeneration dynamics among species. Second, we stress the need to account for the roles of non-drought co-drivers of mortality, particularly the historical legacies of management and land use, in order to understand current patterns of vegetation change and improve predictions of future vegetation dynamics. Finally, we suggest that considering vegetation shifts within biogeographical and successional contexts will improve understanding of the underlying processes and the ecosystem-level implications.

\section{Acknowledgements}

This research has been supported by the Spanish government through grants FUN2FUN (CGL2013-46808-R), SECADIN (CGL2012-3296) and BIOCLIM (CGL2015-67419-R), and by the Catalan government (2014 SGR 453). The discussions facilitated by the grant 'Assessing ecosystem recovery after extreme drought-related dieback events worldwide', funded by the Leverhulme Trust (UK), and by the Ecometas excellence network (CGL2014-53840-REDT), funded by the Spanish government, helped the authors in developing some of the ideas 
presented here. We thank José Luis Ordóñez for his help in crafting Figure 3 and Craig Allen for his kind comments that helped improve a previous version of the manuscript.

\section{References}

Allen, C.D., 2007. Interactions across spatial scales among forest dieback, fire, and erosion in northern New Mexico landscapes. Ecosystems 10, 797-808.

Allen, C.D., Breshears, D.D., 1998. Drought-induced shift of a forest-woodland ecotone: Rapid landscape response to climate variation. Proc. Natl. Acad. Sci. USA 95, $14839-14842$.

Allen, C.D., Breshears, D.D., McDowell, N.G., 2015. On underestimation of global vulnerability to tree mortality and forest die-off from hotter drought in the Anthropocene. Ecosphere 6, 1-55.

Allen, C.D., Macalady, A.K., Chenchouni, H., Bachelet, D., McDowell, N., Vennetier, M., Kitzberger, T., Rigling, A., Breshears, D.D., Hogg, E.H., Gonzalez, P., Fensham, R., Zhang, Z., Lim, J.-H., Castro, J., Demidova, N., Allard, G., Running, S.W., Semerci, A., Cobb, N., 2010. A global overview of drought and heat-induced tree mortality reveals emerging climate change risks for forests. For. Ecol. Manag. 259, 660-684.

Anderegg, L.D.L., Anderegg, W.R.L., Abatzoglou, J., Hausladen, A.M., Berry, J.A., 2013. Drought characteristics' role in widespread aspen forest mortality across Colorado, USA. Glob. Change Biol. 19, 1526-1537.

Anderegg, W.R.L., Flint, A., Huang, C., Flint, L., Berry, J.A., Davis, F.W., Sperry, J.S., Field, C.B., 2015a. Tree mortality predicted from drought-induced vascular damage. Nat. Geosci. 8, 367-371.

Anderegg, W.R.L., Hicke, J.A., Fisher, R.A., Allen, C.D., Aukema, J., Bentz, B., Hood, S., Lichstein, J.W., Macalady, A.K., McDowell, N., Pan, Y., Raffa, K., Sala, A., Shaw, J.D., Stephenson, N.L., Tague, C., Zeppel, M., 2015b. Tree mortality from drought, insects, and their interactions in a changing climate. New Phytol. 208, 674-683.

Anderegg, W.R.L., Kane, J.M., Anderegg, L.D.L., 2012. Consequences of widespread tree mortality triggered by drought and temperature stress. Nat. Clim. Change. 3, 30-36.

Anderegg, W.R.L., Schwalm, C., Biondi, F., Camarero, J.J., Koch, G., Litvak, M., Ogle, K., Shaw, J.D., Shevliakova, E., Williams, A.P., Wolf, A., Ziaco, E., Pacala, S., 2015c. Pervasive drought legacies in forest ecosystems and their implications for carbon cycle models. Science 349, 528-532.

Andersen, T., Carstensen, J., Hernández-García, E., Duarte, C.M., 2009. Ecological thresholds and regime shifts: approaches to identification. Trends Ecol. Evol. 24, 49-57.

Anderson-Teixeira, K.J., Davies, S.J., Bennett, A.C., Gonzalez-Akre, E.B., Muller-Landau, H.C., Joseph Wright, S., Abu Salim, K., Almeyda Zambrano, A.M., Alonso, A., Baltzer, J.L., Basset, Y., Bourg, N.A., Broadbent, E.N., Brockelman, W.Y., Bunyavejchewin, S., Burslem, D.F.R.P., Butt, N., Cao, M., Cardenas, D., Chuyong, G.B., Clay, K., Cordell, S., Dattaraja, H.S., Deng, X., Detto, M., Du, X., Duque, A., Erikson, D.L., Ewango, C.E.N., Fischer, G.A., Fletcher, C., Foster, R.B., Giardina, C.P., Gilbert, G.S., Gunatilleke, N., Gunatilleke, S., Hao, Z., Hargrove, W.W., Hart, T.B., Hau, B.C.H., He, F., Hoffman, F.M., Howe, R.W., Hubbell, S.P., Inman-Narahari, F.M., Jansen, P.A., Jiang, M., Johnson, D.J., Kanzaki, M., Kassim, A.R., Kenfack, D., Kibet, S., Kinnaird, M.F., Korte, L., Kral, K., Kumar, J., Larson, A.J., Li, Y., Li, X., Liu, S., Lum, S.K.Y., Lutz, J.A., Ma, K., Maddalena, D.M., Makana, J.-R., Malhi, Y., Marthews, T., Mat Serudin, R., McMahon, S.M., McShea, W.J., Memiaghe, H.R., Mi, X., Mizuno, T., Morecroft, M., Myers, J.A., Novotny, V., de Oliveira, A.A., Ong, P.S., Orwig, D.A., Ostertag, R., den Ouden, J., Parker, G.G., Phillips, R.P., Sack, L., Sainge, M.N., Sang, W., Sri-ngernyuang, K., Sukumar, R., Sun, I.- 
F., Sungpalee, W., Suresh, H.S., Tan, S., Thomas, S.C., Thomas, D.W., Thompson, J., Turner, B.L., Uriarte, M., Valencia, R., Vallejo, M.I., Vicentini, A., Vrška, T., Wang, X., Wang, X., Weiblen, G., Wolf, A., Xu, H., Yap, S., Zimmerman, J., 2014. CTFS-ForestGEO: a worldwide network monitoring forests in an era of global change. Glob. Change Biol. 21, 528-549.

Asner, G.P., Brodrick, P.G., Anderson, C.B., Vaughn, N., Knapp, D.E., Martin, R.E., 2016. Progressive forest canopy water loss during the 2012-2015 California drought. Proc. Natl. Acad. Sci. 113, E249-E255.

Aynekulu, E., Denich, M., Tsegaye, D., Aerts, R., Neuwirth, B., Boehmer, H.J., 2011. Dieback affects forest structure in a dry Afromontane forest in northern Ethiopia. J. Arid Environ. 75, 499-503.

Bailo, B.G., Emison, M.R.C., Coleman, W.B., Burk, C.J., 2004. Thirty-six years of change in an Eastern Hemlock-White pine stand in Western Massachusetts. Rhodora 106, 273-286.

Batllori, E., Parisien, M.-A., Krawchuk, M.A., Moritz, M.A., 2013. Climate change-induced shifts in fire for Mediterranean ecosystems. Glob. Ecol. Biogeogr. 22, 1118-1129.

Bell, D.M., Bradford, J.B., Lauenroth, W.K., 2014. Early indicators of change: divergent climate envelopes between tree life stages imply range shifts in the western United States. Glob. Ecol. Biogeogr. 23, 168-180.

Bellingham, P.J., Sparrow, A.D., 2000. Resprouting as a life history strategy in woody plant communities. Oikos 89, 409-416.

Bennett, A.C., McDowell, N.G., Allen, C.D., Anderson-Teixeira, K.J., 2015. Larger trees suffer most during drought in forests worldwide. Nat. Plants 1, 15139.

Bentouati, A., 2008. La situation du cèdre de l'Atlas dans les Aurès (Algérie). For. Méditerranéenne 29, 203-208.

Bigler, C., Bräker, O.U., Bugmann, H., Dobbertin, M., Rigling, A., 2006. Drought as an inciting mortality factor in Scots pine stands of the Valais, Switzerland. Ecosystems 9, 330-343.

Boehmer, H.J., Wagner, H.H., Jacobi, J.D., Gerrish, G.C., Mueller-Dombois, D., 2013. Rebuilding after collapse: evidence for long-term cohort dynamics in the native Hawaiian rain forest. J. Veg. Sci. 24, 639-650.

Bonan, G.B., Levis, S., Kergoat, L., Oleson, K.W., 2002. Landscapes as patches of plant functional types: An integrating concept for climate and ecosystem models. Glob. Biogeochem. Cycles 16, 5-1.

Bond, W.J., Midgley, J.J., 2001. Ecology of sprouting in woody plants: the persistence niche. Trends Ecol. Evol. 16, 45-51.

Brando, P.M., Balch, J.K., Nepstad, D.C., Morton, D.C., Putz, F.E., Coe, M.T., Silvério, D., Macedo, M.N., Davidson, E.A., Nóbrega, C.C., Alencar, A., Soares-Filho, B.S., 2014. Abrupt increases in Amazonian tree mortality due to drought-fire interactions. Proc. Natl. Acad. Sci. 111, 6347-6352.

Breshears, D.D., Cobb, N.S., Rich, P.M., Price, K.P., Allen, C.D., Balice, R.G., Romme, W.H., Kastens, J.H., Floyd, M.L., Belnap, J., Anderson, J.J., Myers, O.B., Meyer, C.W., 2005. Regional vegetation die-off in response to global-change-type drought. Proc. Natl. Acad. Sci. U. S. A. 102, 15144-15148.

Brook, B.W., Ellis, E.C., Perring, M.P., Mackay, A.W., Blomqvist, L., 2013. Does the terrestrial biosphere have planetary tipping points? Trends Ecol. Evol. 28, 396-401.

Butt, N., Malhi, Y., New, M., Macía, M.J., Lewis, S.L., Lopez-Gonzalez, G., Laurance, W.F., Laurance, S., Luizão, R., Andrade, A., Baker, T.R., Almeida, S., Phillips, O.L., 2014. Shifting dynamics of climate-functional groups in old-growth Amazonian forests. Plant Ecol. Divers. 7, 267-279.

Cailleret, M., Nourtier, M., Amm, A., Durand-Gillmann, M., Davi, H., 2013. Drought-induced decline and mortality of silver fir differ among three sites in Southern France. Ann. For. Sci. 71, 643-657. 
Calder, J.A., Kirkpatrick, J.B., 2008. Climate change and other factors influencing the decline of the Tasmanian cider gum (Eucalyptus gunnii). Aust. J. Bot. 56, 684-692.

Calò, C., Henne, P.D., Eugster, P., Leeuwen, J. van, Gilli, A., Hamann, Y., Mantia, T.L., Pasta, S., Vescovi, E., Tinner, W., 2013. 1200 years of decadal-scale variability of Mediterranean vegetation and climate at Pantelleria Island, Italy. The Holocene 23, 1477-1486.

Camarero, J.J., Bigler, C., Linares, J.C., Gil-Pelegrín, E., 2011. Synergistic effects of past historical logging and drought on the decline of Pyrenean silver fir forests. For. Ecol. Manag. 262, 759-769.

Canadell, J., López-Soria, L., 1998. Lignotuber reserves support regrowth following clipping of two Mediterranean shrubs. Funct. Ecol. 12, 31-38.

Carnicer, J., Barbeta, A., Sperlich, D., Coll, M., Peñuelas, J., 2013. Contrasting trait syndromes in angiosperms and conifers are associated with different responses of tree growth to temperature on a large scale. Front. Funct. Plant Ecol. 4, 409.

Chaparro, D., 2013. Regional-scale forest decline responds to climatic anomalies and remotely sensed soil moisture. MSc Thesis, Universitat Autònoma de Barcelona, Spain.

Chazdon, R.L., Redondo Brenes, A., Vilchez Alvarado, B., 2005. Effects of climate and stand age on annual tree dynamics in tropical second-growth rain forests. Ecology 86, 18081815.

Choat, B., Jansen, S., Brodribb, T.J., Cochard, H., Delzon, S., Bhaskar, R., Bucci, S.J., Feild, T.S., Gleason, S.M., Hacke, U.G., Jacobsen, A.L., Lens, F., Maherali, H., Martínez-Vilalta, J., Mayr, S., Mencuccini, M., Mitchell, P.J., Nardini, A., Pittermann, J., Pratt, R.B., Sperry, J.S., Westoby, M., Wright, I.J., Zanne, A.E., 2012. Global convergence in the vulnerability of forests to drought. Nature 491, 752-755.

Clarke, P.J., Lawes, M.J., Midgley, J.J., Lamont, B.B., Ojeda, F., Burrows, G.E., Enright, N.J., Knox, K.J.E., 2013. Resprouting as a key functional trait: how buds, protection and resources drive persistence after fire. New Phytol. 197, 19-35.

Clifford, M.J., Booth, R.K., 2015. Late-Holocene drought and fire drove a widespread change in forest community composition in eastern North America. The Holocene 0959683615580182. doi:10.1177/0959683615580182

Condit, R., Hubbell, S.P., Foster, R.B., 1996a. Assessing the response of plant functional types to climatic change in tropical forests. J. Veg. Sci. 7, 405-416.

Condit, R., Hubbell, S.P., Foster, R.B., 1996b. Changes in tree species abundance in a Neotropical forest: impact of climate change. J. Trop. Ecol. 12, 231-256.

Condit, R., Hubbell, S.P., Foster, R.B., 1995. Mortality Rates of 205 Neotropical Tree and Shrub Species and the Impact of a Severe Drought. Ecol. Monogr. 65, 419-439.

Connell, S.D., Ghedini, G., 2015. Resisting regime-shifts: the stabilising effect of compensatory processes. Trends Ecol. Evol. 30, 513-515.

Coop, J.D., Barker, K.J., Knight, A.D., Pecharich, J.S., 2014. Aspen (Populus tremuloides) stand dynamics and understory plant community changes over 46 years near Crested Butte, Colorado, USA. For. Ecol. Manag. 318, 1-12.

del Cacho, M., Lloret, F., 2012. Resilience of Mediterranean shrubland to a severe drought episode: the role of seed bank and seedling emergence. Plant Biol. 14, 458-466.

Dobrowski, S.Z., Swanson, A.K., Abatzoglou, J.T., Holden, Z.A., Safford, H.D., Schwartz, M.K., Gavin, D.G., 2015. Forest structure and species traits mediate projected recruitment declines in western US tree species. Glob. Ecol. Biogeogr. 24, 917-927.

Fauset, S., Baker, T.R., Lewis, S.L., Feldpausch, T.R., Affum-Baffoe, K., Foli, E.G., Hamer, K.C., Swaine, M.D., 2012. Drought-induced shifts in the floristic and functional composition of tropical forests in Ghana. Ecol. Lett. 15, 1120-1129.

Fensham, R.J., Fairfax, R.J., Kenkel, N., 2007. Drought-related tree death of savanna eucalypts: Species susceptibility, soil conditions and root architecture. J. Veg. Sci. 18, 71-80. 
Fensham, R.J., Fairfax, R.J., Ward, D.P., 2009. Drought-induced tree death in savanna. Glob. Change Biol. 15, 380-387.

Fensham, R.J., Holman, J.E., 1999. Temporal and spatial patterns in drought-related tree dieback in Australian savanna. J. Appl. Ecol. 36, 1035-1050.

Floyd, M.L., Romme, W.H., Rocca, M.E., Hanna, D.P., Hanna, D.D., 2015. Structural and regenerative changes in old-growth piñon-juniper woodlands following droughtinduced mortality. For. Ecol. Manag. 341, 18-29.

Foley, J.A., Coe, M.T., Scheffer, M., Wang, G., 2003. Regime Shifts in the Sahara and Sahel: Interactions between Ecological and Climatic Systems in Northern Africa. Ecosystems $6,524-532$.

Folke, C., Carpenter, S., Walker, B., Scheffer, M., Elmqvist, T., Gunderson, L., Holling, C.S., 2004. Regime Shifts, Resilience, and Biodiversity in Ecosystem Management. Annu. Rev. Ecol. Evol. Syst. 35, 557-581.

Foster, D.R., Oswald, W.W., Faison, E.K., Doughty, E.D., Hansen, B.C.S., 2006. A climatic driver for abrupt mid-holocene vegetation dynamics and the hemlock decline in new england. Ecology 87, 2959-2966.

Frelich, L.E., Reich, P.B., 1999. Minireviews: Neighborhood Effects, Disturbance Severity, and Community Stability in Forests. Ecosystems 2, 151-166.

Frey, B.R., Lieffers, V.J., Hogg, E. (Ted), Landhäusser, S.M., 2004. Predicting landscape patterns of aspen dieback: mechanisms and knowledge gaps. Can. J. For. Res. 34, 1379-1390.

Galiano, L., Martínez-Vilalta, J., Eugenio, M., Granzow-de la Cerda, Í., Lloret, F., 2013. Seedling emergence and growth of Quercus spp. following severe drought effects on a Pinus sylvestris canopy. J. Veg. Sci. 24, 580-588.

Galiano, L., Martínez-Vilalta, J., Lloret, F., 2010. Drought-Induced Multifactor Decline of Scots Pine in the Pyrenees and Potential Vegetation Change by the Expansion of Cooccurring Oak Species. Ecosystems 13, 978-991.

Galiano, L., Martínez-Vilalta, J., Sabaté, S., Lloret, F., 2012. Determinants of drought effects on crown condition and their relationship with depletion of carbon reserves in a Mediterranean holm oak forest. Tree Physiol. 32, 478-489.

Garcia-Forner, N., Adams, H.D., Sevanto, S., Collins, A.D., Dickman, L.T., Hudson, P.J., Zeppel, M.J. b., Jenkins, M.W., Powers, H., Martínez-Vilalta, J., Mcdowell, N.G., 2015. Responses of two semiarid conifer tree species to reduced precipitation and warming reveal new perspectives for stomatal regulation. Plant Cell Environ., in press. doi:10.1111/pce.12588

García-Valdés, R., Svenning, J.-C., Zavala, M.A., Purves, D.W., Araújo, M.B., 2015. Evaluating the combined effects of climate and land-use change on tree species distributions. J. Appl. Ecol. 52, 902-912.

Gaylord, M.L., Kolb, T.E., Pockman, W.T., Plaut, J.A., Yepez, E.A., Macalady, A.K., Pangle, R.E., McDowell, N.G., 2013. Drought predisposes piñon-juniper woodlands to insect attacks and mortality. New Phytol. 198, 567-578.

Gimmi, U., Wohlgemuth, T., Rigling, A., Hoffmann, C.W., Bürgi, M., 2010. Land-use and climate change effects in forest compositional trajectories in a dry Central-Alpine valley. Ann. For. Sci. 67, 701-701.

Gitlin, A.R., Sthultz, C.M., Bowker, M.A., Stumpf, S., Paxton, K.L., Kennedy, K., Muñoz, A., Bailey, J.K., Whitham, T.G., 2006. Mortality gradients within and among dominant plant populations as barometers of ecosystem change during extreme drought. Conserv. Biol. 20, 1477-1486.

Gonzalez, P., 2001. Desertification and a shift of forest species in the West African Sahel. Clim. Res. 17, 217-228.

Grant, G.E., Tague, C.L., Allen, C.D., 2013. Watering the forest for the trees: an emerging priority for managing water in forest landscapes. Front. Ecol. Environ. 11, 314-321. 
Grossiord, C., Granier, A., Ratcliffe, S., Bouriaud, O., Bruelheide, H., Chećko, E., Forrester, D.I., Dawud, S.M., Finér, L., Pollastrini, M., Scherer-Lorenzen, M., Valladares, F., Bonal, D., Gessler, A., 2014. Tree diversity does not always improve resistance of forest ecosystems to drought. Proc. Natl. Acad. Sci. 111, 14812-14815.

Grubb, P.J., 1977. The maintenance of species-richness in plant communities: the importance of the regeneration niche. Biol Rev 52, 107-145.

Guarín, A., Taylor, A.H., 2005. Drought triggered tree mortality in mixed conifer forests in Yosemite National Park, California, USA. For. Ecol. Manag. 218, 229-244.

Hanes, T.L., 1971. Succession after Fire in the Chaparral of Southern California. Ecol. Monogr. 41, 27-52.

Hansen, M.C., Potapov, P.V., Moore, R., Hancher, M., Turubanova, S.A., Tyukavina, A., Thau, D., Stehman, S.V., Goetz, S.J., Loveland, T.R., Kommareddy, A., Egorov, A., Chini, L., Justice, C.O., Townshend, J.R.G., 2013. High-Resolution Global Maps of 21st-Century Forest Cover Change. Science 342, 850-853.

Hartmann, H., Adams, H.D., Anderegg, W.R.L., Jansen, S., Zeppel, M.J.B., 2015. Research frontiers in drought-induced tree mortality: crossing scales and disciplines. New Phytol. 205, 965-969.

Hiernaux, P., Diarra, L., Trichon, V., Mougin, E., Soumaguel, N., Baup, F., 2009. Woody plant population dynamics in response to climate changes from 1984 to 2006 in Sahel (Gourma, Mali). J. Hydrol. 375, 103-113.

Higgins, S.I., Scheiter, S., 2012. Atmospheric $\mathrm{CO} 2$ forces abrupt vegetation shifts locally, but not globally. Nature 488, 209-212.

Hilbert, D.W., Roulet, N., Moore, T., 2000. Modelling and analysis of peatlands as dynamical systems. J. Ecol. 88, 230-242.

Hirota, M., Holmgren, M., Nes, E.H.V., Scheffer, M., 2011. Global Resilience of Tropical Forest and Savanna to Critical Transitions. Science 334, 232-235.

Hogg, E.H. (Ted), Brandt, J.P., Michaelian, M., 2008. Impacts of a regional drought on the productivity, dieback, and biomass of western Canadian aspen forests. Can. J. For. Res. 38, 1373-1384.

Hosking, G.P., Hutcheson, J.A., 1988. Mountain beech (Nothofagus solandri var. cliffortioides) decline in the Kaweka Range, North Island, New Zealand. N. Z. J. Bot. 26, 393-400.

Hosking, G.P., Kershaw, D.J., 1985. Red beech death in the Maruia Valley South Island, New Zealand. N. Z. J. Bot. 23, 201-211.

Hughes, T.P., Linares, C., Dakos, V., van de Leemput, I.A., van Nes, E.H., 2013. Living dangerously on borrowed time during slow, unrecognized regime shifts. Trends Ecol. Evol. 28, 149-155.

Ibáñez, B., Gómez-Aparicio, L., Stoll, P., Ávila, J.M., Pérez-Ramos, I.M., Marañón, T., 2015. A Neighborhood Analysis of the Consequences of Quercus suber Decline for Regeneration Dynamics in Mediterranean Forests. PLoS ONE 10, e0117827.

IPCC, 2014. Climate Change 2014: Synthesis Report. Contribution of Working Groups I, II and III to the Fifth Assessment Report of the Intergovernmental Panel on Climate Change [Core Writing Team, R.K. Pachauri and L.A. Meyer (Eds.)]. IPCC, Geneva, Switzerland,

Jackson, S.T., Betancourt, J.L., Booth, R.K., Gray, S.T., 2009. Ecology and the ratchet of events: Climate variability, niche dimensions, and species distributions. Proc. Natl. Acad. Sci. 106, 19685-19692.

Jactel, H., Petit, J., Desprez-Loustau, M.L., Delzon, S., Piou, D., Battisti, A., Koricheva, J., 2011. Drought effects on damage by forest insects and pathogens: a meta-analysis. Glob. Change Biol. 18, 267-276.

Janssen, R.H.H., Meinders, M.B.J., Van NES, E.H., Scheffer, M., 2008. Microscale vegetation-soil feedback boosts hysteresis in a regional vegetation-climate system. Glob. Change Biol. 14, 1104-1112. 
Johnstone, J.F., Chapin, F.S., 2006. Fire interval effects on successional trajectory in boreal forests of northwest Canada. Ecosystems 9, 268-277.

Juday, G.P., Alix, C., Grant III, T.A., 2015. Spatial coherence and change of opposite white spruce temperature sensitivities on floodplains in Alaska confirms early-stage boreal biome shift. For. Ecol. Manag. 350, 46-61.

Jump, A.S., Marchant, R., Peñuelas, J., 2009a. Environmental change and the option value of genetic diversity. Trends Plant Sci. 14, 51-58.

Jump, A.S., Mátyás, C., Peñuelas, J., 2009b. The altitude-for-latitude disparity in the range retractions of woody species. Trends Ecol. Evol. 24, 694-701.

Kéfi, S., Rietkerk, M., Alados, C.L., Pueyo, Y., Papanastasis, V.P., ElAich, A., de Ruiter, P.C., 2007. Spatial vegetation patterns and imminent desertification in Mediterranean arid ecosystems. Nature 449, 213-217.

Klein, T., 2014. The variability of stomatal sensitivity to leaf water potential across tree species indicates a continuum between isohydric and anisohydric behaviors. Funct. Ecol. 28, $1313-1320$.

Laura Suarez, M., Kitzberger, T., 2010. Differential effects of climate variability on forest dynamics along a precipitation gradient in northern Patagonia. J. Ecol. 98, 1023-1034.

Lawrence, P.J., Chase, T.N., 2007. Representing a new MODIS consistent land surface in the Community Land Model (CLM 3.0). J. Geophys. Res. Biogeosciences 112, G01023.

Linares, J.C., Camarero, J.J., Bowker, M.A., Ochoa, V., Carreira, J.A., 2010a. Stand-structural effects on Heterobasidion abietinum-related mortality following drought events in Abies pinsapo. Oecologia 164, 1107-1119.

Linares, J.C., Camarero, J.J., Carreira, J.A., 2010b. Competition modulates the adaptation capacity of forests to climatic stress: insights from recent growth decline and death in relict stands of the Mediterranean fir Abies pinsapo. J. Ecol. 98, 592-603.

Linares, J.C., Taïqui, L., Camarero, J.J., 2011. Increasing Drought Sensitivity and Decline of Atlas Cedar (Cedrus atlantica) in the Moroccan Middle Atlas. Forests 2, 777-796.

Lingenfelder, M., Newbery, D.M., 2009. On the detection of dynamic responses in a droughtperturbed tropical rainforest in Borneo. Plant Ecol. 201, 267-290.

Lloret, F., Escudero, A., Iriondo, J.M., Martínez-Vilalta, J., Valladares, F., 2012. Extreme climatic events and vegetation: the role of stabilizing processes. Glob. Change Biol. 18, 797805.

Lloret, F., Granzow-de la Cerda, I., 2013. Plant competition and facilitation after extreme drought episodes in Mediterranean shrubland: does damage to vegetation cover trigger replacement by juniper woodland? J. Veg. Sci. 24, 1020-1032.

Lloret, F., Mattana, S., Yuste, J.C., 2015. Climate-induced die-off affects plant-soil-microbe ecological relationship and functioning. FEMS Microbiol. Ecol. 91, 1-12.

Lloret, F., Peñuelas, J., Ogaya, R., 2004a. Establishment of co-existing Mediterranean tree species under a varying soil moisture regime. J. Veg. Sci. 15, 237-244.

Lloret, F., Siscart, D., Dalmases, C., 2004b. Canopy recovery after drought dieback in holm-oak Mediterranean forests of Catalonia (NE Spain). Glob. Change Biol. 10, 2092-2099.

Loepfe, L., Rodrigo, A., Lloret, F., 2014. Two thresholds determine climatic control of forest fire size in Europe and northern Africa. Reg. Environ. Change 14, 1395-1404.

Maestre, F.T., Escudero, A., 2009. Is the patch size distribution of vegetation a suitable indicator of desertification processes? Ecology 90, 1729-1735.

Mantgem, P.J. van, Stephenson, N.L., Byrne, J.C., Daniels, L.D., Franklin, J.F., Fulé, P.Z., Harmon, M.E., Larson, A.J., Smith, J.M., Taylor, A.H., Veblen, T.T., 2009. Widespread Increase of Tree Mortality Rates in the Western United States. Science 323, 521-524.

Martínez-Vilalta, J., Lloret, F., Breshears, D.D., 2011. Drought-induced forest decline: causes, scope and implications. Biol. Lett. 8, 689-691. 
Martínez-Vilalta, J., Poyatos, R., Aguadé, D., Retana, J., Mencuccini, M., 2014. A new look at water transport regulation in plants. New Phytol. 204, 105-115.

Matusick, G., Ruthrof, K.X., Brouwers, N.C., Dell, B., Hardy, G.S.J., 2013. Sudden forest canopy collapse corresponding with extreme drought and heat in a mediterranean-type eucalypt forest in southwestern Australia. Eur. J. For. Res. 132, 497-510.

Maza-Villalobos, S., Poorter, L., Martínez-Ramos, M., 2013. Effects of ENSO and Temporal Rainfall Variation on the Dynamics of Successional Communities in Old-Field Succession of a Tropical Dry Forest. PLoS ONE 8, e82040.

McDowell, N.G., Allen, C.D., 2015. Darcy's law predicts widespread forest mortality under climate warming. Nat. Clim. Change 5, 669-672.

McDowell, N.G., Beerling, D.J., Breshears, D.D., Fisher, R.A., Raffa, K.F., Stitt, M., 2011. The interdependence of mechanisms underlying climate-driven vegetation mortality. Trends Ecol. Evol. 26, 523-532.

McDowell, N.G., Coops, N.C., Beck, P.S.A., Chambers, J.Q., Gangodagamage, C., Hicke, J.A., Huang, C., Kennedy, R., Krofcheck, D.J., Litvak, M., Meddens, A.J.H., Muss, J., NegrónJuarez, R., Peng, C., Schwantes, A.M., Swenson, J.J., Vernon, L.J., Williams, A.P., Xu, C., Zhao, M., Running, S.W., Allen, C.D., 2015. Global satellite monitoring of climateinduced vegetation disturbances. Trends Plant Sci. 20, 114-123.

McDowell, N.G., Fisher, R.A., Xu, C., Domec, J.C., Hölttä, T., Mackay, D.S., Sperry, J.S., Boutz, A., Dickman, L., Gehres, N., Limousin, J.M., Macalady, A., Martínez-Vilalta, J., Mencuccini, M., Plaut, J.A., Ogée, J., Pangle, R.E., Rasse, D.P., Ryan, M.G., Sevanto, S., Waring, R.H., Williams, A.P., Yepez, E.A., Pockman, W.T., 2013. Evaluating theories of droughtinduced vegetation mortality using a multimodel-experiment framework. New Phytol. 200, 304-321.

McDowell, N., Pockman, W.T., Allen, C.D., Breshears, D.D., Cobb, N., Kolb, T., Plaut, J., Sperry, J., West, A., Williams, D.G., 2008. Mechanisms of plant survival and mortality during drought: why do some plants survive while others succumb to drought? New Phytol. 178, 719-739.

McDowell, N.G., Williams, A.P., Xu, C., Pockman, W.T., Dickman, L.T., Sevanto, S., Pangle, R., Limousin, J., Plaut, J., Mackay, D.S., Ogee, J., Domec, J.C., Allen, C.D., Fisher, R.A., Jiang, X., Muss, J.D., Breshears, D.D., Rauscher, S.A., Koven, C., 2016. Multi-scale predictions of massive conifer mortality due to chronic temperature rise. Nat. Clim. Change 6 , 295-300.

Meddens, A.J.H., Hicke, J.A., Macalady, A.K., Buotte, P.C., Cowles, T.R., Allen, C.D., 2015. Patterns and causes of observed piñon pine mortality in the southwestern United States. New Phytol. 206, 91-97.

Mencuccini, M., Minunno, F., Salmon, Y., Martínez-Vilalta, J., Hölttä, T., 2015. Coordination of physiological traits involved in drought-induced mortality of woody plants. New Phytol. 208, 396-409.

Millar, C.I., Westfall, R.D., Delany, D.L., 2007. Response of high-elevation limber pine (Pinus flexilis) to multiyear droughts and 20th-century warming, Sierra Nevada, California, USA. Can. J. For. Res. 37, 2508-2520.

Mitchell, P.J., O'Grady, A.P., Hayes, K.R., Pinkard, E.A., 2014. Exposure of trees to droughtinduced die-off is defined by a common climatic threshold across different vegetation types. Ecol. Evol. 4, 1088-1101.

Mohren, G., Hasenauer, H., Köhl, M., Nabuurs, G.-J., 2012. Forest inventories for carbon change assessments. Curr. Opin. Environ. Sustain., 4/6 Climate systems 4, 686-695.

Mokria, M., Gebrekirstos, A., Aynekulu, E., Bräuning, A., 2015. Tree dieback affects climate change mitigation potential of a dry afromontane forest in northern Ethiopia. For. Ecol. Manag. 344, 73-83. 
Morin, X., Fahse, L., de Mazancourt, C., Scherer-Lorenzen, M., Bugmann, H., 2014. Temporal stability in forest productivity increases with tree diversity due to asynchrony in species dynamics. Ecol. Lett. 17, 1526-1535.

Moorcroft, P. R., Hurtt, G. C., \& Pacala, S. W. (2001). A method for scaling vegetation dynamics: The ecosystem demography model (ED). Ecol. Monog. 71, 557-586.

Mountford, E.P., Peterken, G.F., Edwards, P.J., Manners, J.G., 1999. Long-term change in growth, mortality and regeneration of trees in Denny Wood, an old-growth woodpasture in the New Forest (UK). Perspect. Plant Ecol. Evol. Syst. 2, 223-272.

Mueller, R.C., Scudder, C.M., Porter, M.E., Talbot Trotter, R., Gehring, C.A., Whitham, T.G., 2005. Differential tree mortality in response to severe drought: evidence for long-term vegetation shifts. J. Ecol. 93, 1085-1093.

Nakagawa, M., Tanaka, K., Nakashizuka, T., Ohkubo, T., Kato, T., Maeda, T., Sato, K., Miguchi, H., Nagamasu, H., Ogino, K., Teo, S., Hamid, A.A., Seng, L.H., 2000. Impact of severe drought associated with the 1997-1998 El Niño in a tropical forest in Sarawak. J. Trop. Ecol. 16, 355-367.

Nardini, A., Casolo, V., Dal Borgo, A., Savi, T., Stenni, B., Bertoncin, P., Zini, L., McDowell, N.G., 2015. Rooting depth, water relations and non-structural carbohydrate dynamics in three woody angiosperms differentially affected by an extreme summer drought. Plant Cell Environ., in press.

Navarro-Cerrillo, R., Camarero, J., Manzanedo, R., Sánchez-Cuesta, R., Lopez Quintanilla, J., Sánchez Salguero, R., 2014. Regeneration of Abies pinsapo within gaps created by Heterobasidion annosum-induced tree mortality in southern Spain. IForest Biogeosciences For. e1-e7.

Neilson, R. P. 1995. A model for predicting continental-scale vegetation distribution and water balance. Ecol. Appl. 5, 362-385.

Newbery, D.M., Lingenfelder, M., 2008. Plurality of tree species responses to drought perturbation in Bornean tropical rain forest, in: Valk, A.G.V. der (Ed.), Forest Ecology. Springer Netherlands, pp. 147-167.

Niinemets, Ü., Valladares, F., 2006. Tolerance to shade, drought, and waterlogging of temperate northern hemisphere trees and shrubs. Ecol. Monogr. 76, 521-547.

Oatham, M.P., Ramnarine, S., 2006. Dynamics of pioneer and primary successional stage trees in a logged Trinidadian tropical rainforest and the influence of drought. Trop. Ecol. 47, 13-26.

Olano, J.M., Palmer, M.W., 2003. Stand dynamics of an Appalachian old-growth forest during a severe drought episode. For. Ecol. Manag. 174, 139-148.

Oliva, J., Stenlid, J., Martínez-Vilalta, J., 2014. The effect of fungal pathogens on the water and carbon economy of trees: implications for drought-induced mortality. New Phytol. 203, 1028-1035.

Palik, B.J., Ostry, M.E., Venette, R.C., Abdela, E., 2012. Tree regeneration in black ash (Fraxinus nigra) stands exhibiting crown dieback in Minnesota. For. Ecol. Manag. 269, 26-30.

Palik, B.J., Ostry, M.E., Venette, R.C., Abdela, E., 2011. Fraxinus nigra (black ash) dieback in Minnesota: Regional variation and potential contributing factors. For. Ecol. Manag. 261, 128-135.

Parolari, A.J., Katul, G.G., Porporato, A., 2014. An ecohydrological perspective on droughtinduced forest mortality. J. Geophys. Res. Biogeosciences 119, 965-981.

Pausas, J.G., Llovet, J., Rodrigo, A., Vallejo, R., 2009. Are wildfires a disaster in the Mediterranean basin?-A review. Int. J. Wildland Fire 17, 713-723.

Pausas, J.G., Pratt, R.B., Keeley, J.E., Jacobsen, A.L., Ramirez, A.R., Vilagrosa, A., Paula, S., Kaneakua-Pia, I.N., Davis, S.D., 2015. Towards understanding resprouting at the global scale. New Phytol., in press. doi:10.1111/nph.13644 
Peng, C., Ma, Z., Lei, X., Zhu, Q., Chen, H., Wang, W., Liu, S., Li, W., Fang, X., Zhou, X., 2011. A drought-induced pervasive increase in tree mortality across Canada's boreal forests. Nat. Clim. Change 1, 467-471.

Peterken, G.F., Jones, E.W., 1987. Forty Years of Change in Lady Park Wood: The Old-Growth Stands. J. Ecol. 75, 477-512.

Petraitis, P., 2013. Multiple Stable States in Natural Ecosystems. Oxford University Press, Oxford, UK.

Phillips, O.L., Aragão, L.E.O.C., Lewis, S.L., Fisher, J.B., Lloyd, J., López-González, G., Malhi, Y., Monteagudo, A., Peacock, J., Quesada, C.A., 2009. Drought sensitivity of the Amazon rainforest. Science 323, 1344-1347.

Pironon, S., Villellas, J., Morris, W.F., Doak, D.F., García, M.B., 2015. Do geographic, climatic or historical ranges differentiate the performance of central versus peripheral populations? Glob. Ecol. Biogeogr. 24, 611-620.

Potts, B.M., Potts, W.C., Kantvilas, G., 2001. The Miena cider gum, Eucalyptus gunnii subsp. divaricata (Myrtaceae): a taxon in rapid decline. Pap. Proc. R. Soc. Tasman. 135, 57-61.

Pratt, R.B., Jacobsen, A.L., Mohla, R., Ewers, F.W., Davis, S.D., 2008. Linkage between water stress tolerance and life history type in seedlings of nine chaparral species (Rhamnaceae). J. Ecol. 96, 1252-1265.

Quétier, F., Thébault, A., Lavorel, S., 2007. Plant traits in a state and transition framework as markers of ecosystem response to land-use change. Ecol. Monogr. 77, 33-52.

Redmond, M.D., Barger, N.N., 2013. Tree regeneration following drought- and insect-induced mortality in piñon-juniper woodlands. New Phytol. 200, 402-412.

Redmond, M.D., Cobb, N.S., Clifford, M.J., Barger, N.N., 2015. Woodland recovery following drought-induced tree mortality across an environmental stress gradient. Glob. Change Biol. 21, 3685-3695.

Reyer, C.P.O., Brouwers, N., Rammig, A., Brook, B.W., Epila, J., Grant, R.F., Holmgren, M., Langerwisch, F., Leuzinger, S., Lucht, W., Medlyn, B., Pfeifer, M., Steinkamp, J., Vanderwel, M.C., Verbeeck, H., Villela, D.M., 2015. Forest resilience and tipping points at different spatio-temporal scales: approaches and challenges. J. Ecol. 103, 5-15.

Rice, K.J., Matzner, S.L., Byer, W., Brown, J.R., 2004. Patterns of tree dieback in Queensland, Australia: the importance of drought stress and the role of resistance to cavitation. Oecologia 139, 190-198.

Rietkerk, M., Dekker, S.C., Ruiter, P.C. de, Koppel, J. van de, 2004. Self-Organized Patchiness and Catastrophic Shifts in Ecosystems. Science 305, 1926-1929.

Rigling, A., Bigler, C., Eilmann, B., Feldmeyer-Christe, E., Gimmi, U., Ginzler, C., Graf, U., Mayer, P., Vacchiano, G., Weber, P., Wohlgemuth, T., Zweifel, R., Dobbertin, M., 2013. Driving factors of a vegetation shift from Scots pine to pubescent oak in dry Alpine forests. Glob. Change Biol. 19, 229-240.

Rodrigo, A., Retana, J., Picó, F.X., 2004. Direct regeneration is not the only response of Mediterranean forests to large fires. Ecology 85, 716-729.

Romme, W.H., Allen, C.D, Bailey, J.D, Baker, W.L., Bestelmeyer, B.T., Brown, P.M., Eisenhart, K.S., Floyd, M.L., Huffman, D.W., Jacobs, B.F., Miller, R.F., Muldavin, E.H., Swetnam, T.W., Tausch, R.J., Weisberg, P.J., 2009. Historical and Modern Disturbance Regimes, Stand Structures, and Landscape Dynamics in Piñon-Juniper Vegetation of the Western United States. Rangeland Ecol. Manag. 62, 203-222.

Sala, A., Piper, F., Hoch, G., 2010. Physiological mechanisms of drought-induced tree mortality are far from being resolved. New Phytol. 186, 274-281.

Sánchez-Salguero, R., Navarro-Cerrillo, R.M., Swetnam, T.W., Zavala, M.A., 2012. Is drought the main decline factor at the rear edge of Europe? The case of southern Iberian pine plantations. For. Ecol. Manag. 271, 158-169. 
Sanger, J.C., Davidson, N.J., O'grady, A.P., Close, D.C., 2011. Are the patterns of regeneration in the endangered Eucalyptus gunnii ssp. divaricata shifting in response to climate? Austral Ecol. 36, 612-620.

Sangüesa-Barreda, G., Camarero, J.J., Oliva, J., Montes, F., Gazol, A., 2015. Past logging, drought and pathogens interact and contribute to forest dieback. Agric. For. Meteorol. 208, 85-94.

Sapés, G., 2013. Drought-induced effects in coexisting Mediterranean shrubs in relation to species' bioclimatic niche, MSc Thesis, Universitat Autonoma Barcelona, Spain.

Saura-Mas, S., Bonas, A., Lloret, F., 2014. Plant community response to drought-induced canopy defoliation in a Mediterranean Quercus ilex forest. Eur. J. For. Res. 134, 261272.

Saura-Mas, S., Lloret, F., 2010. Foliar stable carbon and nitrogen isotopes in woody Mediterranean species with different life form and post-fire regeneration. Plant Biol. $12,125-133$.

Savage, M. 1997. The role of anthropogenic influences in a mixed-conifer forest mortality episode. J. Veg. Sci. 8, 95-104.

Scheffer, M., Carpenter, S., Foley, J.A., Folke, C., Walker, B., 2001. Catastrophic shifts in ecosystems. Nature 413, 591-596.

Scheffer, M., Carpenter, S.R., 2003. Catastrophic regime shifts in ecosystems: linking theory to observation. Trends Ecol. Evol. 18, 648-656.

Scheffer, M., Carpenter, S.R., Lenton, T.M., Bascompte, J., Brock, W., Dakos, V., van de Koppel, J., van de Leemput, I.A., Levin, S.A., van Nes, E.H., Pascual, M., Vandermeer, J., 2012. Anticipating Critical Transitions. Science 338, 344-348.

Scheffer, M., Hirota, M., Holmgren, M., Nes, E.H.V., Chapin, F.S., 2012. Thresholds for boreal biome transitions. Proc. Natl. Acad. Sci. 109, 21384-21389.

Schmieder, J., Fritz, S.C., Grimm, E.C., Jacobs, K.C., Brown, K.J., Swinehart, J.B., Porter, S.C., 2013. Holocene variability in hydrology, vegetation, fire, and eolian activity in the Nebraska Sand Hills, USA. The Holocene 23, 515-527.

Sevanto, S., Mcdowell, N.G., Dickman, L.T., Pangle, R., Pockman, W.T., 2014. How do trees die? A test of the hydraulic failure and carbon starvation hypotheses. Plant Cell Environ. 37, 153-161.

Shugart, H.H., Urban, D.L. 1989. Factors affecting the relative abundances of forest tree species. In: Grubb, P.J, Whittaker, J.B (Eds.), Toward a more exact ecology. Blackwell Scientific, Oxford, UK, pp 249-273.

Shuman, B.N., Newby, P., Donnelly, J.P., 2009. Abrupt climate change as an important agent of ecological change in the Northeast U.S. throughout the past 15,000 years. Quat. Sci. Rev., Quaternary Ice Sheet-Ocean Interactions and Landscape Responses 28, 16931709.

Siefert, A., Violle, C., Chalmandrier, L., Albert, C.H., Taudiere, A., Fajardo, A., Aarssen, L.W., Baraloto, C., Carlucci, M.B., Cianciaruso, M.V., de L. Dantas, V., de Bello, F., Duarte, L.D.S., Fonseca, C.R., Freschet, G.T., Gaucherand, S., Gross, N., Hikosaka, K., Jackson, B., Jung, V., Kamiyama, C., Katabuchi, M., Kembel, S.W., Kichenin, E., Kraft, N.J.B., Lagerström, A., Bagousse-Pinguet, Y.L., Li, Y., Mason, N., Messier, J., Nakashizuka, T., Overton, J.M., Peltzer, D.A., Pérez-Ramos, I.M., Pillar, V.D., Prentice, H.C., Richardson, S., Sasaki, T., Schamp, B.S., Schöb, C., Shipley, B., Sundqvist, M., Sykes, M.T., Vandewalle, M., Wardle, D.A., 2015. A global meta-analysis of the relative extent of intraspecific trait variation in plant communities. Ecol. Lett. 18, 1406-1419.

Sitch, S., Smith, B., Prentice, I.C., Arneth, A., Bondeau, A., Cramer, W., Kaplan, J.O., Levis, S., Lucht, W., Sykes, M.T., Thonicke, K., Venevsky, S., 2003. Evaluation of ecosystem 
dynamics, plant geography and terrestrial carbon cycling in the LPJ dynamic global vegetation model. Glob. Change Biol. 9, 161-185.

Slik, J.W.F., 2004. El Niño droughts and their effects on tree species composition and diversity in tropical rain forests. Oecologia 141, 114-120.

Smith, W.K., Germino, M.J., Johnson, D.M., Reinhardt, K., 2009. The Altitude of Alpine Treeline: A Bellwether of Climate Change Effects. Bot. Rev. 75, 163-190.

Steinkamp, J., Hickler, T., 2015. Is drought-induced forest dieback globally increasing? J. Ecol. 103, 31-43.

Suarez, M.L., Ghermandi, L., Kitzberger, T., 2004. Factors predisposing episodic droughtinduced tree mortality in Nothofagus- site, climatic sensitivity and growth trends. J. Ecol. 92, 954-966.

Suarez, M.L., Kitzberger, T., 2008. Recruitment patterns following a severe drought: long-term compositional shifts in Patagonian forests. Can. J. For. Res. 38, 3002-3010.

Suarez, M.L., Sasal, Y., 2012. Drought-induced mortality affects understory vegetation: release after death. Ecol. Res. 27, 715-724.

Swetnam, T.W., Allen, C.D., Betancourt, J.L., 1999. Applied Historical Ecology: Using the Past to Manage for the Future. Ecol. Appl. 9, 1189-1206.

Swetnam, T.W., Betancourt, J.L., 1998. Mesoscale disturbance and ecological response to decadal climatic variability in the American Southwest. J. Climate 11, 3128-3147.

Tang, G., Beckage, B., 2010. Projecting the distribution of forests in New England in response to climate change. Divers. Distrib. 16, 144-158.

Thuiller, W., Albert, C., Araújo, M.B., Berry, P.M., Cabeza, M., Guisan, A., Hickler, T., Midgley, G.F., Paterson, J., Schurr, F.M., Sykes, M.T., Zimmermann, N.E., 2008. Predicting global change impacts on plant species' distributions: Future challenges. Perspect. Plant Ecol. Evol. Syst. 9, 137-152.

Trabaud, L., Lepart, J., 1980. Diversity and Stability in Garrigue Ecosystems After Fire. In: Maarel, E. van der (Ed.), Succession, Advances in Vegetation Science. Springer Netherlands, pp. 49-57.

Trumbore, S., Brando, P., Hartmann, H., 2015. Forest health and global change. Science 349, 814-818.

Twidwell, D., Wonkka, C.L., Taylor, C.A., Zou, C.B., Twidwell, J.J., Rogers, W.E., 2014. Droughtinduced woody plant mortality in an encroached semi-arid savanna depends on topoedaphic factors and land management. Appl. Veg. Sci. 17, 42-52.

Valladares, F., Matesanz, S., Guilhaumon, F., Araújo, M.B., Balaguer, L., Benito-Garzón, M., Cornwell, W., Gianoli, E., van Kleunen, M., Naya, D.E., Nicotra, A.B., Poorter, H., Zavala, M.A., 2014. The effects of phenotypic plasticity and local adaptation on forecasts of species range shifts under climate change. Ecol. Lett. 17, 1351-1364.

Valladares, F., Niinemets, Ü., 2008. Shade tolerance, a key plant feature of complex nature and consequences. Annu. Rev. Ecol. Evol. Syst. 39, 237-257.

Van Mantgem, P.J., Stephenson, N.L., 2007. Apparent climatically induced increase of tree mortality rates in a temperate forest. Ecol. Lett. 10, 909-916.

van Nes, E.H., Hirota, M., Holmgren, M., Scheffer, M., 2014. Tipping points in tropical tree cover: linking theory to data. Glob. Change Biol. 20, 1016-1021.

Vesk, P.A., Westoby, M., 2004. Sprouting ability across diverse disturbances and vegetation types worldwide. J. Ecol. 92, 310-320.

Vicente-Serrano, S.M., Gouveia, C., Camarero, J.J., Beguería, S., Trigo, R., López-Moreno, J.I., Azorín-Molina, C., Pasho, E., Lorenzo-Lacruz, J., Revuelto, J., Morán-Tejeda, E., Sanchez-Lorenzo, A., 2013. Response of vegetation to drought time-scales across global land biomes. Proc. Natl. Acad. Sci. 110, 52-57.

Vilà-Cabrera, A., Martínez-Vilalta, J., Galiano, L., Retana, J., 2013. Patterns of Forest Decline and Regeneration Across Scots Pine Populations. Ecosystems 16, 323-335. 
Vilà-Cabrera, A., Martínez-Vilalta, J., Retana, J., 2015. Functional trait variation along environmental gradients in temperate and Mediterranean trees. Glob. Ecol. Biogeogr. 24, 1377-1389.

Vilà-Cabrera, A., Martínez-Vilalta, J., Vayreda, J., Retana, J., 2010. Structural and climatic determinants of demographic rates of Scots pine forests across the Iberian Peninsula. Ecol. Appl. 21, 1162-1172. doi:10.1890/10-0647.1

Villalba, R., Veblen, T.T., 1998. Influences of large-scale climatic variability on episodic tree mortality in northern Patagonia. Ecology 79, 2624-2640.

von Arx, G., Graf Pannatier, E., Thimonier, A., Rebetez, M., 2013. Microclimate in forests with varying leaf area index and soil moisture: potential implications for seedling establishment in a changing climate. J. Ecol. 101, 1201-1213.

White, P.S., Jentsch, A., 2001. The Search for Generality in Studies of Disturbance and Ecosystem Dynamics. Progress in Botany 62, 399-450.

Williams, A.P., Allen, C.D., Macalady, A.K., Griffin, D., Woodhouse, C.A., Meko, D.M., Swetnam, T.W., Rauscher, S.A., Seager, R., Grissino-Mayer, H.D., Dean, J.S., Cook, E.R., Gangodagamage, C., Cai, M., McDowell, N.G., 2013. Temperature as a potent driver of regional forest drought stress and tree mortality. Nat. Clim. Change. 3, 292-297.

Williams, J.W., Post, D.M., Cwynar, L.C., Lotter, A.F., Levesque, A.J., 2002. Rapid and widespread vegetation responses to past climate change in the North Atlantic region. Geology 30, 971-974.

Woodward,F.I., 1987. Climate and Plant Distribution. Cambridge University Press, Cambridge, UK.

Worrall, J.J., Egeland, L., Eager, T., Mask, R.A., Johnson, E.W., Kemp, P.A., Shepperd, W.D., 2008. Rapid mortality of Populus tremuloides in southwestern Colorado, USA. For. Ecol. Manag. 255, 686-696.

Worrall, J.J., Marchetti, S.B., Egeland, L., Mask, R.A., Eager, T., Howell, B., 2010. Effects and etiology of sudden aspen decline in southwestern Colorado, USA. For. Ecol. Manag. 260, 638-648.

Zeeman, B.J., Lunt, I.D., Morgan, J.W., 2014. Can severe drought reverse woody plant encroachment in a temperate Australian woodland? J. Veg. Sci. 25, 928-936.

Zeppel, M.J.B., Harrison, S.P., Adams, H.D., Kelley, D.I., Li, G., Tissue, D.T., Dawson, T.E., Fensham, R., Medlyn, B.E., Palmer, A., West, A.G., McDowell, N.G., 2014. Drought and resprouting plants. New Phytol. 206, 583-589.

Zeppenfeld, T., Svoboda, M., DeRose, R.J., Heurich, M., Müller, J., Čížková, P., Starý, M., Bače, R., Donato, D.C., 2015. Response of mountain Picea abies forests to stand-replacing bark beetle outbreaks: neighbourhood effects lead to self-replacement. J. Appl. Ecol. $52,1402-1411$.

Zhang, X., Lei, Y., Pang, Y., Liu, X., Wang, J., 2014. Tree mortality in response to climate change induced drought across Beijing, China. Clim. Change 124, 179-190.

Zhou, G., Houlton, B.Z., Wang, W., Huang, W., Xiao, Y., Zhang, Q., Liu, S., Cao, M., Wang, X., Wang, S., Zhang, Y., Yan, J., Liu, J., Tang, X., Zhang, D., 2014. Substantial reorganization of China's tropical and subtropical forests: based on the permanent plots. Glob. Change Biol. 20, 240-250.

Zhou, G., Peng, C., Li, Y., Liu, S., Zhang, Q., Tang, X., Liu, J., Yan, J., Zhang, D., Chu, G., 2013. A climate change-induced threat to the ecological resilience of a subtropical monsoon evergreen broad-leaved forest in Southern China. Glob. Change Biol. 19, 1197-1210. 


\section{Invited review for Global and Planetary Change}

\section{Tables and Figures}

Table 1. Case studies of 'drought-induced vegetation shifts' included in the literature review. Codes indicating type of change are explained in Figure 1. ID numbers correspond to those indicated in Figure 2 .

\begin{tabular}{|c|c|c|c|c|c|c|c|c|c|c|c|c|c|c|c|c|}
\hline ID & Name & Location & Climate & $\begin{array}{l}\text { Vegetatio } \\
n \text { type }\end{array}$ & $\begin{array}{c}\text { Drought } \\
\text { period }\end{array}$ & $\begin{array}{l}\text { Scale of } \\
\text { impact }\end{array}$ & $\begin{array}{l}\text { Affected } \\
\text { dominant } \\
\text { species or } \\
\text { veg. type }\end{array}$ & $\begin{array}{c}\text { Replacing } \\
\text { species or } \\
\text { vegetation } \\
\text { type }\end{array}$ & $\begin{array}{l}\text { Funct. } \\
\text { type } \\
\text { shift* }\end{array}$ & $\begin{array}{c}\text { Survival } \\
\text { replacing } \\
\text { species? }\end{array}$ & $\begin{array}{l}\text { Regener. } \\
\text { affected } \\
\text { species? }\end{array}$ & $\begin{array}{l}\text { Regener. } \\
\text { replacing } \\
\text { species? }\end{array}$ & $\begin{array}{c}\text { Type } \\
\text { of } \\
\text { change }\end{array}$ & $\begin{array}{l}\text { Abridged } \\
\text { type of } \\
\text { change }\end{array}$ & $\begin{array}{c}\text { Other } \\
\text { contributing } \\
\text { factors }\end{array}$ & References \\
\hline 1 & $\begin{array}{c}\text { Afromontane } \\
\text { forest } \\
\text { Ethiopia }\end{array}$ & N Ethiopia & Dry & Forest & $\begin{array}{l}\text { Late } \\
\text { 1980s }\end{array}$ & Local & $\begin{array}{c}\text { Juniperus } \\
\text { procera, Olea } \\
\text { europapea }\end{array}$ & $\begin{array}{c}\text { Early } \\
\text { successional } \\
\text { shrubs }\end{array}$ & $\begin{array}{c}\text { NET + } \\
\text { BET -> } \\
\text { BES }\end{array}$ & Yes & Low & na & $\begin{array}{c}\mathrm{UNb} / \\
\mathrm{SSf}\end{array}$ & UN & Management & (1) (2) \\
\hline 2 & Atlas Cedar & N Morocco & Medit. & Forest & $\begin{array}{l}1993, \\
1995, \\
1999\end{array}$ & Regional & $\begin{array}{c}\text { Cedrus } \\
\text { atlantica }\end{array}$ & $\begin{array}{l}\text { Quercus } \\
\text { rotundifolia }\end{array}$ & $\begin{array}{c}\text { NET -> } \\
\text { BET }\end{array}$ & Yes & na (low) & (Yes) & SSf & ss & $\begin{array}{c}\text { Management } \\
\text {, biotic } \\
\text { agents }\end{array}$ & (3) (4) \\
\hline 3 & $\begin{array}{c}\text { Sahel } \\
\text { woodlands } \\
\text { Mali }\end{array}$ & Gourma, Mali & Dry & Woodland & $\begin{array}{c}1983- \\
1984\end{array}$ & Regional & $\begin{array}{l}\text { Acacia spp, } \\
\text { Combretum } \\
\text { glutinosum }\end{array}$ & Shrubland & $\begin{array}{c}\text { BDT -> } \\
\text { BDS }\end{array}$ & na & Yes & Yes & $\begin{array}{l}\text { Una / } \\
\text { UNc }\end{array}$ & UN & Grazing & (5) \\
\hline 4 & $\begin{array}{c}\text { Sahel } \\
\text { woodlands } \\
\text { Senegal }\end{array}$ & NW Senegal & Dry & Woodland & $\begin{array}{l}1968- \\
1973\end{array}$ & $\begin{array}{l}\text { Regional } \\
\text { (ecotone) }\end{array}$ & $\begin{array}{c}\text { Taller trees } \\
\text { with larger } \\
\text { leaves }\end{array}$ & $\begin{array}{l}\text { Short, thorny } \\
\text { trees }\end{array}$ & $\begin{array}{c}\text { BET -> } \\
\text { BDT }\end{array}$ & na & na & na & BS & BS & Management & (6) \\
\hline 5 & $\begin{array}{l}\text { Appalachian } \\
\text { Forest E USA }\end{array}$ & $\begin{array}{c}\text { North } \\
\text { Carolina, USA }\end{array}$ & Temp. & Forest & $\begin{array}{l}1984- \\
1989\end{array}$ & Local & $\begin{array}{c}\text { Tilia } \\
\text { americana, } \\
\text { Fagus } \\
\text { grandifolia }\end{array}$ & $\begin{array}{c}\text { Acer } \\
\text { saccharum, } \\
\text { Aesculus } \\
\text { flava }\end{array}$ & $\begin{array}{c}\text { BDT -> } \\
\text { BDT }\end{array}$ & Yes & Yes & Yes & UNa & UN & Succession & (7) \\
\hline 6 & Ash NE USA & NE USA & Temp. & Forest & $\begin{array}{l}1990 \mathrm{~s}- \\
2000 \mathrm{~s}\end{array}$ & Regional & $\begin{array}{c}\text { Fraxinus } \\
\text { nigra }\end{array}$ & Shrubland & $\begin{array}{c}\text { BDT -> } \\
\text { BDS }\end{array}$ & (Yes) & Low & Low & $\begin{array}{c}\text { UNb / } \\
\text { BS }\end{array}$ & UN & $\begin{array}{c}\text { Biotic agents, } \\
\text { hydrologcal } \\
\text { alterations, }\end{array}$ & (8) (9) \\
\hline
\end{tabular}


Invited review for Global and Planetary Change

\begin{tabular}{|c|c|c|c|c|c|c|c|c|c|c|c|c|c|c|c|c|}
\hline & & & & & & & & & & & & & & & pollution & \\
\hline 7 & $\begin{array}{l}\text { Aspen decline } \\
\text { N America }\end{array}$ & $\begin{array}{c}\text { Western N } \\
\text { America }\end{array}$ & $\begin{array}{c}\text { Temp. / } \\
\text { Boreal }\end{array}$ & Forest & $2000 \mathrm{~s}$ & $\begin{array}{c}\text { Subconti } \\
\text { nental }\end{array}$ & $\begin{array}{c}\text { Populus } \\
\text { tremuloides }\end{array}$ & $\begin{array}{l}\text { Conifers / } \\
\text { Shrubland }\end{array}$ & $\begin{array}{c}\text { BDT -> } \\
\text { NET + } \\
\text { BDS }\end{array}$ & (Yes) & Low & (Low) & $\begin{array}{l}\text { UNb / } \\
\text { BS }\end{array}$ & UN & $\begin{array}{c}\text { Biotic agents, } \\
\text { succession, } \\
\text { grazing }\end{array}$ & $(10)-(15)$ \\
\hline 8 & $\begin{array}{c}\text { Austrocedrus } \\
\text { Patagonia }\end{array}$ & $\begin{array}{c}\text { N Patagonia, } \\
\text { Argentina }\end{array}$ & Dry & Woodland & $1950 \mathrm{~s}$ & $\begin{array}{l}\text { Regional } \\
\text { (ecotone) }\end{array}$ & $\begin{array}{c}\text { Austrocedrus } \\
\text { chilensis }\end{array}$ & na & na & na & (Yes) & na & $\begin{array}{c}\text { UN / } \\
\text { RV / SR }\end{array}$ & UN & $\begin{array}{c}\text { Wildfires, } \\
\text { grazing }\end{array}$ & (16) \\
\hline 9 & $\begin{array}{l}\text { Conifers } \\
\text { California }\end{array}$ & $\begin{array}{c}\text { Sierra } \\
\text { Nevada, } \\
\text { California, } \\
\text { USA }\end{array}$ & $\begin{array}{l}\text { Medit. } \\
\text { montane }\end{array}$ & Forest & $\begin{array}{l}1985- \\
1995 \\
2000 s\end{array}$ & Regional & $\begin{array}{c}\text { Mixed } \\
\text { coniferous } \\
\text { forest }\end{array}$ & na & na & na & Yes & na & $\begin{array}{c}\text { UN / } \\
\text { RV / SR }\end{array}$ & UN & $\begin{array}{c}\text { Fire } \\
\text { suppression, } \\
\text { biotic agents }\end{array}$ & $(17)-(20)$ \\
\hline $\begin{array}{l}1 \\
0\end{array}$ & $\begin{array}{l}\text { Evergreen } \\
\text { rainforest } \\
\text { Trinidad }\end{array}$ & $\begin{array}{c}\text { Trinidad and } \\
\text { Tobago }\end{array}$ & Tropical & Forest & $\begin{array}{c}1987- \\
1988, \\
1994- \\
1995\end{array}$ & Local & $\begin{array}{l}\text { Primary } \\
\text { species }\end{array}$ & Pioneers & $\begin{array}{c}\text { BET -> } \\
\text { BET }\end{array}$ & Yes & Yes & Yes & UNa & UN & $\begin{array}{c}\text { Succession, } \\
\text { logging }\end{array}$ & (21) \\
\hline $\begin{array}{l}1 \\
1\end{array}$ & $\begin{array}{c}\text { Hemlock NE } \\
\text { USA }\end{array}$ & $\begin{array}{c}\text { Massacgusett } \\
\text { s, USA }\end{array}$ & Temp. & Forest & $\begin{array}{l}1963- \\
1975\end{array}$ & Regional & $\begin{array}{c}\text { Tsuga } \\
\text { canadensis }\end{array}$ & $\begin{array}{c}\text { Pinus } \\
\text { strobus, Acer } \\
\text { rubrum }\end{array}$ & $\begin{array}{c}\text { NET -> } \\
\text { NET + } \\
\text { BDT }\end{array}$ & Yes & Yes & Yes & UNa & UN & $\begin{array}{c}\text { Biotic agents, } \\
\text { windstorms }\end{array}$ & (22) \\
\hline $\begin{array}{l}1 \\
2\end{array}$ & $\begin{array}{c}\text { Metrosideros } \\
\text { Hawaii }\end{array}$ & Hawaii, USA & Tropical & Forest & $\begin{array}{l}1954- \\
1985\end{array}$ & Regional & $\begin{array}{l}\text { Metrosideros } \\
\text { polymorpha }\end{array}$ & na & $\begin{array}{c}\text { BET -> } \\
\text { BET }\end{array}$ & na & Yes & na & $S R$ & SR & $\begin{array}{c}\text { Cohort } \\
\text { senescence }\end{array}$ & (23) \\
\hline $\begin{array}{l}1 \\
3\end{array}$ & $\begin{array}{l}\text { Nothofagus } \\
\text { Patagonia }\end{array}$ & $\begin{array}{c}\text { N Patagonia, } \\
\text { Argentina }\end{array}$ & Temp. & Forest & $\begin{array}{l}1998- \\
1999\end{array}$ & $\begin{array}{l}\text { Regional } \\
\text { (ecotone) }\end{array}$ & $\begin{array}{c}\text { Nothofagus } \\
\text { dombeyi }\end{array}$ & $\begin{array}{c}\text { Austrocedrus } \\
\text { chilensis }\end{array}$ & $\begin{array}{c}\text { BET -> } \\
\text { NET }\end{array}$ & Yes & Low & Yes & SSf & SS & na & $(24)-(27)$ \\
\hline $\begin{array}{l}1 \\
4\end{array}$ & $\begin{array}{c}\text { Oak-Juniper S } \\
\text { USA }\end{array}$ & Texas, USA & Dry & Woodland & $\begin{array}{l}\text { 1951- } \\
1957 \\
2000 s\end{array}$ & Local & $\begin{array}{c}\text { Quercus } \\
\text { virginiana, } \\
\text { Quercus } \\
\text { pungens }\end{array}$ & $\begin{array}{c}\text { Juniperus } \\
\text { ashei }\end{array}$ & $\begin{array}{c}\text { BET -> } \\
\text { NET }\end{array}$ & Yes & Yes & Yes & UNa & UN & Grazing & (28) \\
\hline $\begin{array}{l}1 \\
5\end{array}$ & $\begin{array}{l}\text { Piñon-Juniper } \\
\text { SW USA }\end{array}$ & SW USA & Dry & Woodland & $\begin{array}{l}1996 \\
2002- \\
2005\end{array}$ & Regional & Pinus edulis & $\begin{array}{c}\text { Juniperus } \\
\text { monosperma } \\
/ \mathrm{J} .\end{array}$ & $\begin{array}{c}\text { NET -> } \\
\text { NES }\end{array}$ & Yes & Yes / No & Yes & $\begin{array}{l}\text { SSf / } \\
\text { UNa }\end{array}$ & UN & $\begin{array}{c}\text { Biotic agents, } \\
\text { wildfires }\end{array}$ & $(29)-(33)$ \\
\hline
\end{tabular}


Invited review for Global and Planetary Change

\begin{tabular}{|c|c|c|c|c|c|c|c|c|c|c|c|c|c|c|c|c|}
\hline & & & & & & & & osteosperma & & & & & & & & \\
\hline $\begin{array}{l}1 \\
6\end{array}$ & $\begin{array}{l}\text { Rainforests } \\
\text { Costa Rica }\end{array}$ & NE Costa Rica & Tropical & Forest & $\begin{array}{l}1997- \\
1998\end{array}$ & Local & $\begin{array}{c}\text { Secondary } \\
\text { lowland } \\
\text { rainforest }\end{array}$ & na & $\begin{array}{c}\text { BES -> } \\
\text { BES }\end{array}$ & na & (Yes) & (Yes) & $\begin{array}{l}\text { Una / } \\
\text { UNc }\end{array}$ & UN & $\begin{array}{c}\text { Grazing, } \\
\text { succession }\end{array}$ & (34) \\
\hline $\begin{array}{l}1 \\
7\end{array}$ & $\begin{array}{c}\text { Tropical Dry } \\
\text { Forests } \\
\text { Mexico }\end{array}$ & $\begin{array}{l}\text { Jalisco, } \\
\text { Mexico }\end{array}$ & Tropical & Forest & 2005 & Local & Trees & Shrubs & $\begin{array}{c}\text { BDT -> } \\
\text { BDS }\end{array}$ & Low & Yes & Yes & Unc & UN & $\begin{array}{c}\text { Succession, } \\
\text { biotic agents, } \\
\text { grazing }\end{array}$ & (35) \\
\hline $\begin{array}{l}1 \\
8\end{array}$ & $\begin{array}{c}\text { Tropical } \\
\text { forest } \\
\text { Amazonia }\end{array}$ & Amazonia & Tropical & Forest & 1990s & $\begin{array}{c}\text { Subconti } \\
\text { nental }\end{array}$ & Wet-affiliates & Dry-affiliates & $\begin{array}{c}\text { BET -> } \\
\text { BET }\end{array}$ & Yes & Yes & Yes & UNa & UN & $\begin{array}{c}\text { Other } \\
\text { disturbances, } \\
\text { succession }\end{array}$ & (36) \\
\hline $\begin{array}{l}1 \\
9\end{array}$ & $\begin{array}{l}\text { Tropical } \\
\text { Forests } \\
\text { Panama }\end{array}$ & $\begin{array}{c}\text { Barro } \\
\text { Colorado } \\
\text { Island, } \\
\text { Panama }\end{array}$ & Tropical & Forest & 1983 & Local & Wet-affiliates & Dry-affiliates & $\begin{array}{c}\text { BET -> } \\
\text { BET }\end{array}$ & (Yes) & (Low) & (Yes) & SSf & SS & na & $(37)-(39)$ \\
\hline $\begin{array}{l}2 \\
0\end{array}$ & Beijing China & Beijing, China & Temp. & Forest & $\begin{array}{l}1986- \\
2006\end{array}$ & Regional & Quercus sp. & $\begin{array}{c}\text { Pinus } \\
\text { tabuliformis }\end{array}$ & $\begin{array}{c}\text { BDT -> } \\
\text { NET }\end{array}$ & Yes & na & na & $\begin{array}{l}\text { UN / } \\
\text { RV / } \\
\text { SSf }\end{array}$ & UN & Air pollution & (40) \\
\hline $\begin{array}{l}2 \\
1\end{array}$ & $\begin{array}{c}\text { Tropical and } \\
\text { subtropical } \\
\text { China }\end{array}$ & S China & Tropical & Forest & $\begin{array}{l}\text { 1990s- } \\
2000 s\end{array}$ & $\begin{array}{c}\text { Subconti } \\
\text { nental }\end{array}$ & $\begin{array}{c}\text { Tall and } \\
\text { intermediate } \\
\text { trees }\end{array}$ & $\begin{array}{l}\text { Shrubs and } \\
\text { small trees }\end{array}$ & $\begin{array}{c}\text { BET -> } \\
\text { BES }\end{array}$ & Yes & Low & Yes & SSf & SS & na & (41) (42) \\
\hline $\begin{array}{l}2 \\
2\end{array}$ & $\begin{array}{c}\text { Tropical } \\
\text { forest } \\
\text { Sarawak }\end{array}$ & $\begin{array}{l}\text { Sarawak, } \\
\text { Malaysia }\end{array}$ & Tropical & Forest & $\begin{array}{l}1997- \\
1998\end{array}$ & Local & $\begin{array}{l}\text { Dipterocarpa- } \\
\quad \text { ceae }\end{array}$ & na & na & Yes & (Yes) & (Yes) & $\begin{array}{l}\text { UN / } \\
\text { RV / } \\
\text { SSf }\end{array}$ & UN & na & (43) \\
\hline $\begin{array}{l}2 \\
3\end{array}$ & $\begin{array}{c}\text { Tropical } \\
\text { rainforest } \\
\text { Borneo }\end{array}$ & $\begin{array}{c}\text { Sabah and } \\
\text { East } \\
\text { Kalimantan, } \\
\text { Borneo }\end{array}$ & Tropical & Forest & $\begin{array}{l}1997- \\
1998\end{array}$ & Regional & Large trees & Small trees & $\begin{array}{c}\text { BET -> } \\
\text { BET }\end{array}$ & Yes & Yes & Yes & UNa & UN & $\begin{array}{l}\text { Logging, } \\
\text { succession }\end{array}$ & $(44)-(46)$ \\
\hline 2 & Coastal & S Victoria, & Temp. & Woodland & 1997- & Local & Eucalyptus & Allocasuarin & BET -> & Low & No & Low & SSf & SS & Fire & (47) \\
\hline
\end{tabular}


Invited review for Global and Planetary Change

\begin{tabular}{|c|c|c|c|c|c|c|c|c|c|c|c|c|c|c|c|c|}
\hline 4 & $\begin{array}{l}\text { woodland } \\
\text { Australia }\end{array}$ & Australia & & & 2009 & & spp. & $\begin{array}{c}\text { a littoralis, } A . \\
\text { verticillata }\end{array}$ & BET & & & & & & $\begin{array}{l}\text { exclusion, } \\
\text { succession }\end{array}$ & \\
\hline $\begin{array}{l}2 \\
5\end{array}$ & $\begin{array}{l}\text { Eucalyptus } \\
\text { Queensland }\end{array}$ & $\begin{array}{c}\text { Queensland, } \\
\text { Australia }\end{array}$ & Dry & Woodland & $\begin{array}{l}1990 s- \\
2000 s\end{array}$ & Regional & $\begin{array}{c}\text { Eucalyptus } \\
\text { crebra, E. } \\
\text { xanthoclada, } \\
\text { E. } \\
\text { melanophloia } \\
\text { E. populnea }\end{array}$ & $\begin{array}{c}\text { Corymbia } \\
\text { spp. }\end{array}$ & $\begin{array}{c}\text { BET -> } \\
\text { BET }\end{array}$ & Yes & Yes & Yes & UNa & UN & $\begin{array}{l}\text { Grazing, } \\
\text { wildfires }\end{array}$ & $(48)-(50)$ \\
\hline $\begin{array}{l}2 \\
6\end{array}$ & $\begin{array}{l}\text { Eucalyptus } \\
\text { Tasmania }\end{array}$ & $\begin{array}{c}\text { Central } \\
\text { Plateau, } \\
\text { Tasmania, } \\
\text { Australia }\end{array}$ & Temp. & Forest & $\begin{array}{l}1990 s- \\
2000 s\end{array}$ & Local & $\begin{array}{l}\text { Eucalyptus } \\
\text { gunnii ssp. } \\
\text { divaricata }\end{array}$ & $\begin{array}{l}\text { Eucalyptus } \\
\text { pauciflora }\end{array}$ & $\begin{array}{c}\text { BET -> } \\
\text { BET }\end{array}$ & Yes & Low & Yes & SSf & SS & Grazing & $(51)-(53)$ \\
\hline $\begin{array}{l}2 \\
7\end{array}$ & $\begin{array}{c}\text { Eucalyptus } \\
\text { Western } \\
\text { Australia }\end{array}$ & $\begin{array}{l}\text { Western } \\
\text { Australia }\end{array}$ & Medit. & Woodland & $\begin{array}{l}2010- \\
2011\end{array}$ & Regional & $\begin{array}{l}\text { Eucalyptus } \\
\text { marginata }\end{array}$ & $\begin{array}{l}\text { Corymbia } \\
\text { calophylla }\end{array}$ & $\begin{array}{c}\text { BET -> } \\
\text { BET }\end{array}$ & Yes & Yes & Yes & UNa & UN & Biotic agents & (54) \\
\hline $\begin{array}{l}2 \\
8\end{array}$ & $\begin{array}{l}\text { Nothofagus } \\
\text { New Zealand }\end{array}$ & $\begin{array}{l}\text { S Island, New } \\
\text { Zealand }\end{array}$ & Temp. & Forest & $1970 \mathrm{~s}$ & Local & $\begin{array}{c}\text { Nothofagus } \\
\text { fusca }\end{array}$ & $\begin{array}{c}\text { Nothofagus } \\
\text { menziesii }\end{array}$ & $\begin{array}{c}\text { BET -> } \\
\text { BET }\end{array}$ & Yes & Yes & Yes & UNa & UN & Biotic agents & (55) \\
\hline $\begin{array}{l}2 \\
9\end{array}$ & $\begin{array}{l}\text { Nothofagus } \\
\text { New Zealand }\end{array}$ & $\begin{array}{c}\text { N Island, New } \\
\text { Zealand }\end{array}$ & Temp. & Forest & $1970 \mathrm{~s}$ & Local & $\begin{array}{c}\text { Nothofagus } \\
\text { solandri }\end{array}$ & na & $\begin{array}{c}\text { BET -> } \\
\text { BET }\end{array}$ & na & Yes & na & $S R$ & SR & $\begin{array}{c}\text { Biotic agents, } \\
\text { succession }\end{array}$ & (56) \\
\hline $\begin{array}{l}3 \\
0\end{array}$ & $\begin{array}{l}\text { Beech } \\
\text { England }\end{array}$ & S England & Temp. & Forest & $\begin{array}{l}1976, \\
1980 s\end{array}$ & Local & $\begin{array}{c}\text { Fagus } \\
\text { sylvatica }\end{array}$ & $\begin{array}{c}\text { Fraxinus } \\
\text { excelsior / } \\
\text { Quercus } \\
\text { robur }\end{array}$ & $\begin{array}{c}\text { BDT -> } \\
\text { BDT }\end{array}$ & Yes & No & Yes / No & $\begin{array}{l}\text { SSf / } \\
\text { UNb }\end{array}$ & UN & $\begin{array}{c}\text { Biotic agents, } \\
\text { windthrow }\end{array}$ & (57) (58) \\
\hline $\begin{array}{l}3 \\
1\end{array}$ & $\begin{array}{l}\text { Evergreen } \\
\text { oaks Spain }\end{array}$ & Spain & Medit. & $\begin{array}{c}\text { Forest / } \\
\text { Woodland }\end{array}$ & $\begin{array}{l}\text { 1990s, } \\
2000 s\end{array}$ & Regional & $\begin{array}{c}\text { Quercus ilex, } \\
\text { Quercus } \\
\text { suber }\end{array}$ & Shrubs & $\begin{array}{c}\text { BET -> } \\
\text { BES }\end{array}$ & Yes & Yes & Yes & UNa & UN & Biotic agents & $(58)-(63)$ \\
\hline $\begin{array}{l}3 \\
2\end{array}$ & Fir S Europe & S Europe & $\begin{array}{l}\text { Medit. } \\
\text { montane }\end{array}$ & Forest & $\begin{array}{l}1980 s- \\
2000 s\end{array}$ & Regional & Abies alba & $\begin{array}{c}\text { Pinus } \\
\text { sylvestris, }\end{array}$ & $\begin{array}{l}\text { NET -> } \\
\text { NET + }\end{array}$ & na & na & na & UN & UN & $\begin{array}{c}\text { Biotic agents, } \\
\text { logging }\end{array}$ & $(64)-(66)$ \\
\hline
\end{tabular}




\begin{tabular}{|c|c|c|c|c|c|c|c|c|c|c|c|c|c|c|c|c|}
\hline & & & & & & & & $\begin{array}{l}\text { Fagus } \\
\text { sylvatica }\end{array}$ & BDT & & & & & & & \\
\hline $\begin{array}{l}3 \\
3\end{array}$ & Pinsapo Spain & S Spain & $\begin{array}{l}\text { Medit. } \\
\text { montane }\end{array}$ & Forest & $\begin{array}{c}1990 s \text { - } \\
2000 \text { s }\end{array}$ & Local & Abies pinsapo & $\begin{array}{l}\text { Quercus ilex, } \\
\text { Q. faginea, } \\
\text { Juniperus } \\
\text { oxycedrus }\end{array}$ & $\begin{array}{c}\mathrm{NET}-> \\
\mathrm{BET}+\mathrm{B} \\
\mathrm{DT}+\mathrm{NE} \\
\mathrm{S}\end{array}$ & Yes & Yes & Yes & UNa & UN & $\begin{array}{c}\text { Management } \\
\text {, biotic } \\
\text { agents }\end{array}$ & (67) $-(69)$ \\
\hline $\begin{array}{l}3 \\
4\end{array}$ & $\begin{array}{l}\text { Scots pine } \\
\text { Europe }\end{array}$ & $\begin{array}{c}\text { Central \& S } \\
\text { Europe }\end{array}$ & $\begin{array}{l}\text { Medit. } \\
\text { montane } \\
\text { / Temp. }\end{array}$ & Forest & $\begin{array}{c}1990 s \text { - } \\
2000 \mathrm{~s}\end{array}$ & Regional & $\begin{array}{c}\text { Pinus } \\
\text { sylvestris }\end{array}$ & Quercus spp. & $\begin{array}{c}\text { NET -> } \\
\text { BET+B } \\
\text { DT }\end{array}$ & Yes & Low & Yes & SSf & ss & $\begin{array}{c}\text { Management } \\
\text { successional, } \\
\text { biotic agents }\end{array}$ & (70) - (75) \\
\hline $\begin{array}{l}3 \\
5\end{array}$ & $\begin{array}{l}\text { Shrublands } \\
\text { SW Spain }\end{array}$ & $\begin{array}{l}\text { Doñana, S } \\
\text { Spain }\end{array}$ & Medit. & Shrubland & 2005 & Local & $\begin{array}{c}\text { Halimium } \\
\text { halimifolium, } \\
\text { Rosmarinus } \\
\text { officinalis, } \\
\text { Cistus } \\
\text { libanotis }\end{array}$ & na & $\begin{array}{c}\text { BES -> } \\
\text { BES }\end{array}$ & na & Yes & na & SR & SR & na & (76) (77) \\
\hline
\end{tabular}

* Note: NET, needleleaf evergreen tree; BET, broadleaf evergreen tree; BDT, broadleaf deciduous tree; BES, broadleaf evergreen shrub; BDS, broadleaf deciduous shrub; NES, needleleaf evergreen shrub. References: (1) Aynekulu et al., 2011, (2) Mokria et al., 2015, (3) Bentouati, 2008, (4) Linares et al., 2011, (5) Hiernaux et al., 2009, (6) Gonzalez, 2001, (7) Olano and Palmer, 2003, (8) Palik et al., 2011, (9) Palik et al., 2012, (10) Frey et al., 2004, (11) Hogg et al., 2008, (12) Worrall et al., 2008, (13) Worrall et al., 2010, (14) Anderegg et al., 2013, (15) Coop et al., 2014, (16) Villalba and Veblen, 1998, (17) Savage 1997, (18) Guarín and Taylor, 2005, (19) Millar et al., 2007, (20) Van Mantgem and Stephenson, 2007, (21) Oatham and Ramnarine, 2006, (22) Bailo et al., 2004, (23) Boehmer et al., 2013, (24) Suarez et al., 2004, (25) Suarez and Kitzberger, 2008, (26) Suarez and Kitzberger, 2010, (27) Suarez and Sasal, 2012, (28) Twidwell et al., 2014, (29) Breshears et al., 2005, (30) Mueller et al., 2005, (31) Redmond and Barger, 2013, (32) Floyd et al., 2015, (33) Redmond et al., 2015, (34) Chazdon et al., 2005, (35) Maza-Villalobos et al., 2013, (36) Butt et al., 2014, (37) Condit et al., 1995, (38) Condit et al., 1996a, (39) Condit et al., 1996b, (40) Zhang et al., 2014, (41) Zhou et al., 2013, (42) Zhou et al., 2014, (43) Nakagawa et al., 2000, (44) Slik, 2004, (45) Newbery and Lingenfelder, 2008, 
(46) Lingenfelder and Newbery, 2009, (47) Zeeman et al., 2014, (48) Fensham and Holman, 1999, (49) Rice et al., 2004, (50) Fensham et al., 2007, (51) Potts et al., 2001, (52) Calder and Kirkpatrick, 2008, (53) Sanger et al., 2011, (54) Matusick et al., 2013, (55) Hosking and Kershaw, 1985, (56) Hosking and

Hutcheson, 1988, (57) Peterken and Jones, 1987, (58) Mountford et al., 1999, (59) Lloret et al., 2004b, (60) Lloret et al., 2004a, (61) Galiano et al., 2012, (62) Ibáñez et al., 2015, (63) Saura-Mas et al., 2014, (64) Camarero et al., 2011, (65) Cailleret et al., 2013, (66) Sangüesa-Barreda et al., 2015, (67) Linares et al., 2010b, (68) Linares et al., 2010a, (69) Navarro-Cerrillo et al., 2014, (70) Bigler et al., 2006, (71) Gimmi et al., 2010, (72) Galiano et al., 2010, (73) Galiano et al., 2013, (74) Vilà-Cabrera et al., 2013, (75) Rigling et al., 2013, (76) del Cacho and Lloret, 2012, (77) Lloret et al., 2015. 
Figure 1. A framework to classify potential community dynamics after drought-induced mortality. The reference time frame for this classification is the typical generation time of the dominant species in the community (i.e., a shift will occur if the identity of the dominant species changes after one generation).

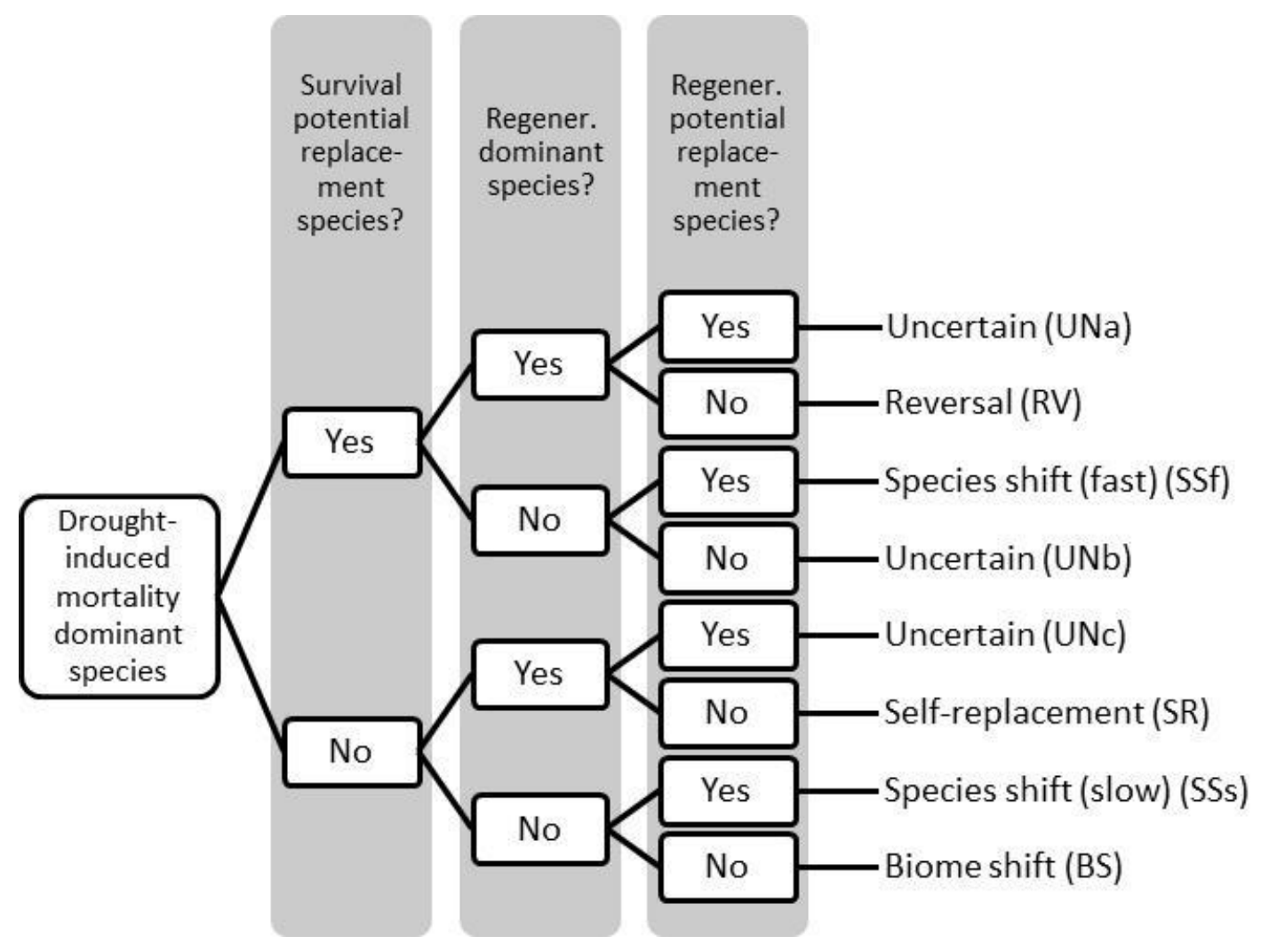


Figure 2. Approximate locations of case studies of possible vegetation shifts considered in this study. Individual case studies are classified according to the framework presented in Figure 1 (abridged as in Table 1: UN, uncertain; SR, self-replacement; SS, species shift; BS, biome shift). Case numbers correspond to ID numbers in Table 1. Note that all symbols have the same size irrespective of the spatial extent of the mortality event they represent.

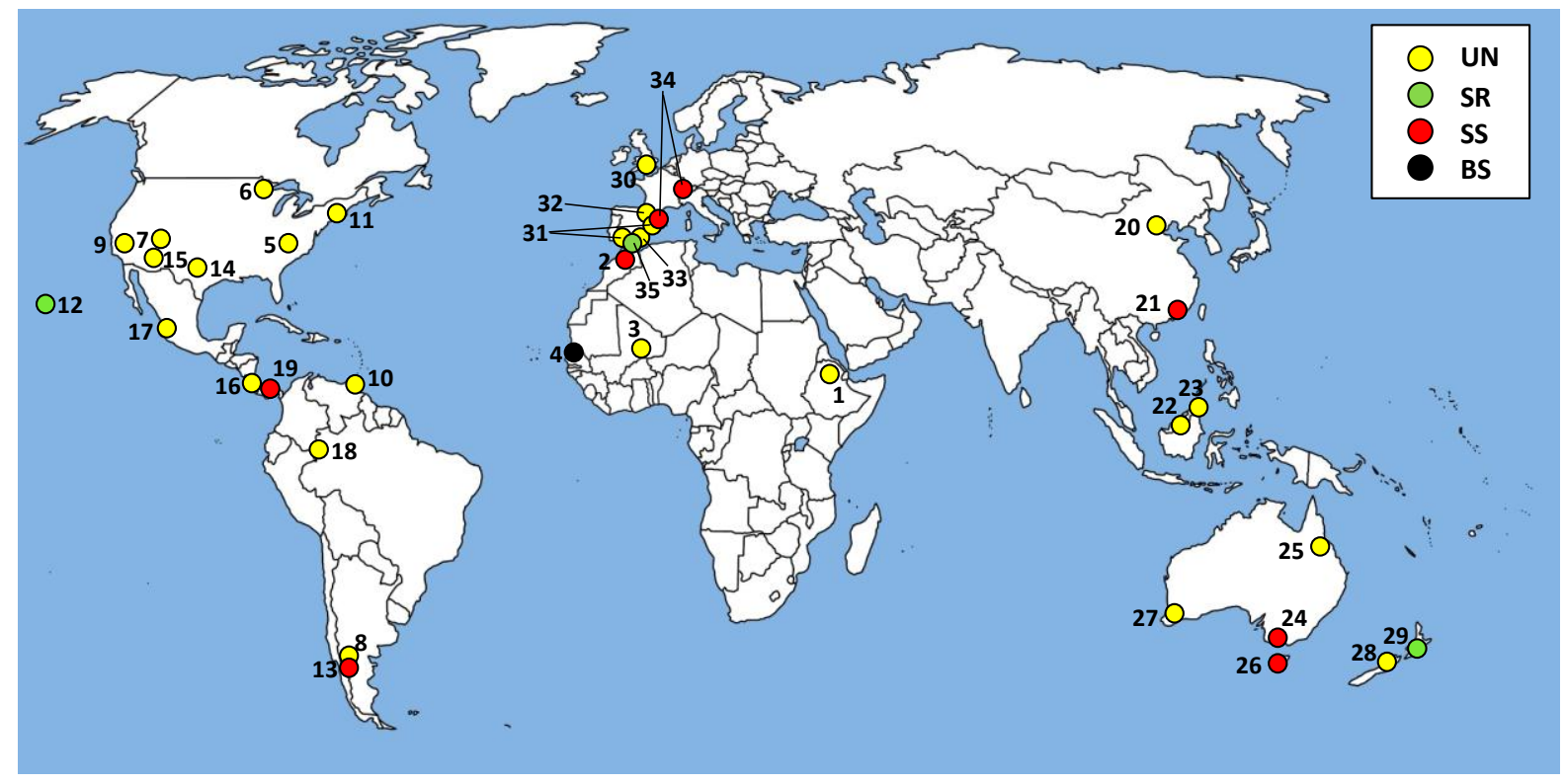


Figure 3. Frequency of transitions between and within functional types reported in the case studies of possible vegetation shifts considered in this study. Arrows connect the functional type corresponding to the affected dominant species and the functional type of the potentially potential replacement species. Red arrows correspond to cases classified as species or biome shift (SSf, SSs or BS in Figure 1) and black arrows to the rest of cases (all other categories in Figure 1). Arrow thickness is proportional to the number of cases (also numerically noted with each arrow). NET, needleleaf evergreen tree; $\mathrm{BET}$, broadleaf evergreen tree; $\mathrm{BDT}$, broadleaf deciduous tree; BES, broadleaf evergreen shrub; BDS, broadleaf deciduous shrub; NES, needleleaf evergreen shrub.

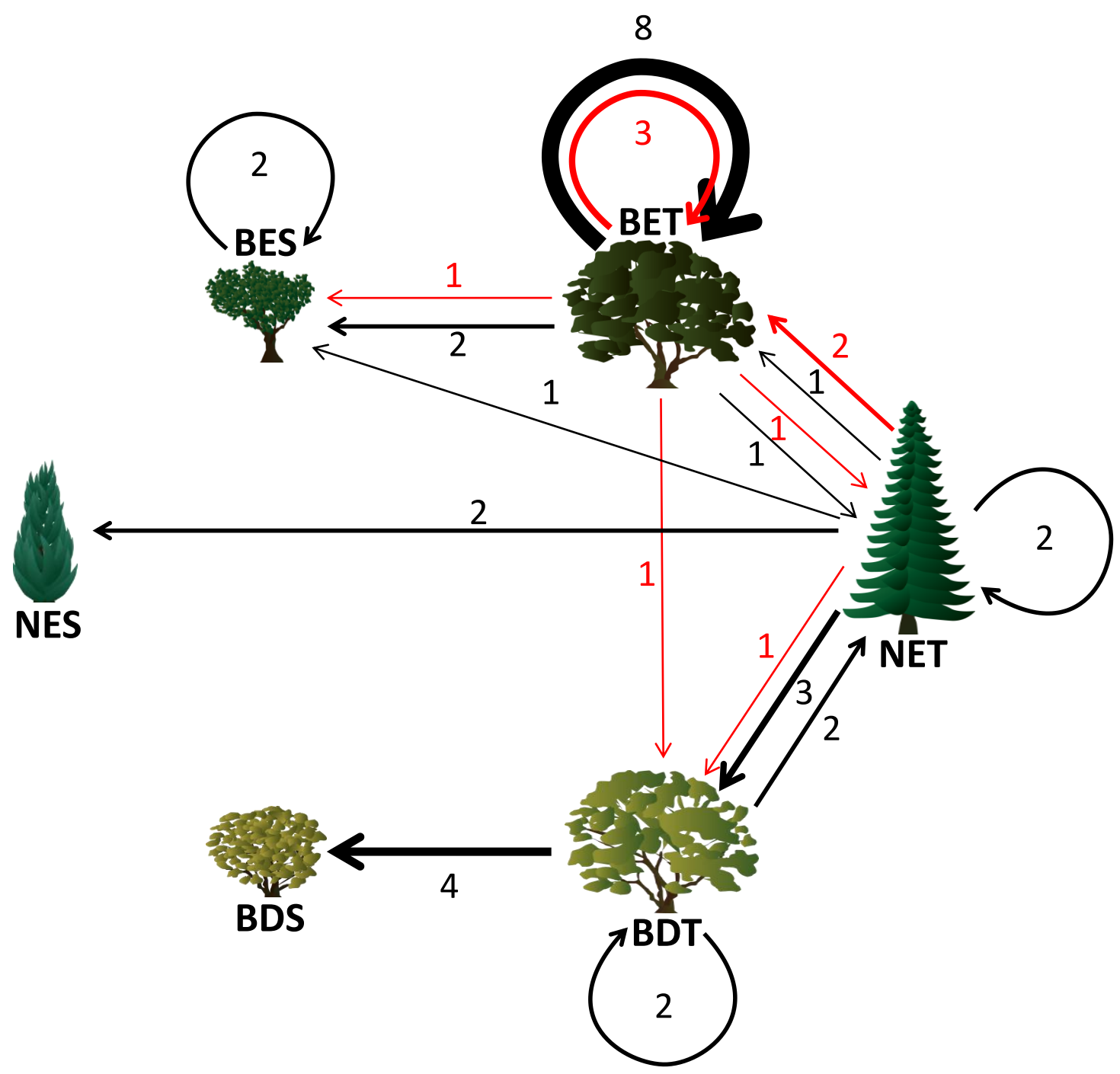

